\title{
Direct and cross price elasticities of demand for gasoline, diesel, hybrid and battery electric cars: the case of Norway
}

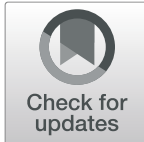

Lasse Fridstrøm ${ }^{*}$ and Vegard Østli

\begin{abstract}
Aim: The primary goals of this research is (i) to derive direct and cross demand market response functions for automobile powertrains and their energy carriers and (ii) to assess how $\mathrm{CO}_{2}$ emissions from automobiles depend on vehicle and energy prices

Methods: The market demand for automobiles with differing powertrains is studied by means of a discrete choice model. Statistically precise coefficient estimates are calculated by means of a highly disaggregate data set consisting of virtually all 1.8 million new passenger car transactions in Norway during 2002-2016. Having estimated the model, we derive market response parameters in the form of direct and cross price elasticities of demand for gasoline, diesel, ordinary hybrid, plug-in hybrid and battery electric cars.

Results: The own-price elasticity of gasoline driven cars is estimated at -1.08 , and those of diesel driven, battery electric and plug-in hybrid electric cars at $-0.99,-1.27$ and -1.72 , respectively, as of 2016 in Norway. The cross price elasticities of demand for gasoline cars with respect to the price of diesel cars, and vice versa, are estimated at 0.64 and 0.51 , while the cross price elasticities of demand for battery electric cars with respect to the prices of gasoline and diesel driven cars come out at 0.36 and 0.48 , respectively. A $1 \%$ increase in the price of liquid fuel in general is found to reduce the average type approval rate of $\mathrm{CO}_{2}$ emission from new passenger cars by an estimated $0.19 \%$.

Conclusion: Fiscal policy measures affecting the prices of vehicles and fuel have a considerable potential for changing the long term composition of the vehicle fleet and its energy consumption, climate footprint and general environmental impact.
\end{abstract}

Keywords: Automobiles, Powertrain, Energy, Technology, Nested logit model, Disaggregate

\section{Introduction}

When car manufacturers, car dealers or fuel companies set prices, or when policymakers are to determine the tax level, they have an interest in knowing how the demand for the product(s) in question responds to price changes. The direct (own) price elasticity measures how much demand would change following a small - say, $1 \%$ - change in the product's price.

\footnotetext{
*Correspondence: lef@toino

Institute of Transport Economics (TØI), Oslo, Norway
}

There is a large scientific literature on the direct price elasticity of demand for gasoline and/or diesel - see, e.g., the excellent review article by Dahl [9] or the metaanalyses by Brons et al. [5] and Labandeira et al. [44]. Dahl [9] remarks:

“... hundreds of studies have focused on measuring such elasticities for gasoline and diesel fuel consumption."

To the extent, however, that there is a policy interest in switching between gasoline and diesel consumption, or in substituting decarbonized energy carriers for fossil

\section{Springer Open}

() The Author(s). 2021 Open Access This article is licensed under a Creative Commons Attribution 4.0 International License, which permits use, sharing, adaptation, distribution and reproduction in any medium or format, as long as you give appropriate credit to the original author(s) and the source, provide a link to the Creative Commons licence, and indicate if changes were made. The images or other third party material in this article are included in the article's Creative Commons licence, unless indicated otherwise in a credit line to the material. If material is not included in the article's Creative Commons licence and your intended use is not permitted by statutory regulation or exceeds the permitted use, you will need to obtain permission directly from the copyright holder. To view a copy of this licence, visit http://creativecommons.org/licenses/by/4.0/. 
fuel, the cross price elasticities of demand between energy carriers commands at least as much interest as the direct price elasticities. The cross price elasticity measures how much the demand for a certain product changes when the price of another product increases. A high cross price elasticity between any two products would suggest that they are close substitutes.

The number of published scientific papers estimating cross price elasticities between liquid fuel and electricity, or between internal combustion engine (ICE) vehicles and battery electric vehicles (BEVs), seems to be nil. Even estimates of the cross price elasticities between traditional fuels like gasoline and diesel seem hard to come by. Although Labandeira et al. [44], in their comprehensive meta-analysis, do consider several energy carriers, including electricity, they find no studies providing empirical cross price elasticity estimates. Says Dahl [9]:

"Technical changes along with numerous country policies have encouraged fuel switching, most often away from gasoline toward diesel fuel, but sometimes towards natural gas or biodiesel. [...] I was not able to find consistent evidence of cross-price elasticities to measure the effect of these policies."

The primary goal of our paper is to help bridge this intriguing knowledge gap, by proposing a methodology to estimate of the cross price elasticities between powertrains and energy carriers for private cars.

A secondary goal is to assess the elasticities of demand for automobiles with varying powertrains, not only with respect to the retail prices of the vehicles themselves, but also with respect to their energy costs. As a corollary, we expect to reveal the car buyers' willingness to pay for future energy savings.

A third objective is to estimate the elasticities of greenhouse gas (GHG) emissions with respect to the prices of new passenger cars and energy.

There are, we think, at least two reasons why the literature on cross price elasticities between powertrains and energy carriers is so scant. First, vehicles are durable assets equipped with a particular energy technology (powertrain). With few exceptions, such as the use or blending-in of biofuel, single-vehicle households are not free to switch to a different energy carrier. This implies that short term cross elasticities are bound to be close to zero - almost not worthwhile to investigate.

Two-car or multi-car households may, however, face a choice as to which vehicle to use for a particular trip. There is thus a limited room for short term fuel or energy carrier substitution at the household level. Utility maximizing households might be expected to prefer the cheaper option in terms of energy costs. Despite its higher energy content, diesel is, in most European countries, sold at a lower price per liter than gasoline. Adding to this competitive advantage is the fact that the diesel engine is slightly superior to the gasoline engine in terms of energy efficiency. But all ICEs are, in this respect, much inferior to the electric motor.

Second, it is difficult to reliably estimate cross price elasticities with respect to a product that hardly exists in the market, or that is present with only a negligible market share, such as battery or plug-in hybrid electric vehicles.

The present authors are in a position to overcome both of these difficulties. Unlike the situation in virtually all other countries, the market for electric cars in Norway has reached sufficient maturity for the five major vehicle energy technologies - gasoline, diesel, ordinary hybrid, plug-in hybrid and battery electric - to exhibit comparable market shares, with 29, 31, 11, 13 and $16 \%$, respectively, as of 2016 (Fig. 1). Although demand elasticities do depend on market shares, and must be expected to change with the continued development of electric vehicle technology and economies of scale, the Norwegian auto market is already sufficiently balanced for meaningful cross demand elasticities to be derived.

Relying on a comprehensive disaggregate discrete choice model of automobile purchase in Norway, we set out to estimate direct and cross price elasticities of demand between cars with five different energy technologies.

A brief literature survey is presented in the next section. In Section 3, we describe, as a background to our modeling and analysis, the main characteristics of the Norwegian automobile market, and in particular its response to the fiscal and regulatory incentives applied over the last couple of decades. In Section 4 we describe our disaggregate discrete choice model of automobile purchase. Results from estimation and counterfactual simulations on the model are set out in Section 5. Some qualifications are discussed in Section 6, and conclusions are drawn in Section 7. A couple of scatterplots describing our data set are shown in the Appendix.

\section{Literature review}

At the household level, the basic choice between energy carriers is made, for a long time ahead, when the vehicle is acquired. Thus one way to understand the degree of substitution between energy carriers would be to study the market for automobiles with differing powertrains.

Among the early attempts to analyse the demand for various types of automobiles we find Lave and Train [45], Manski and Sherman [46], Berkovec [2], and 


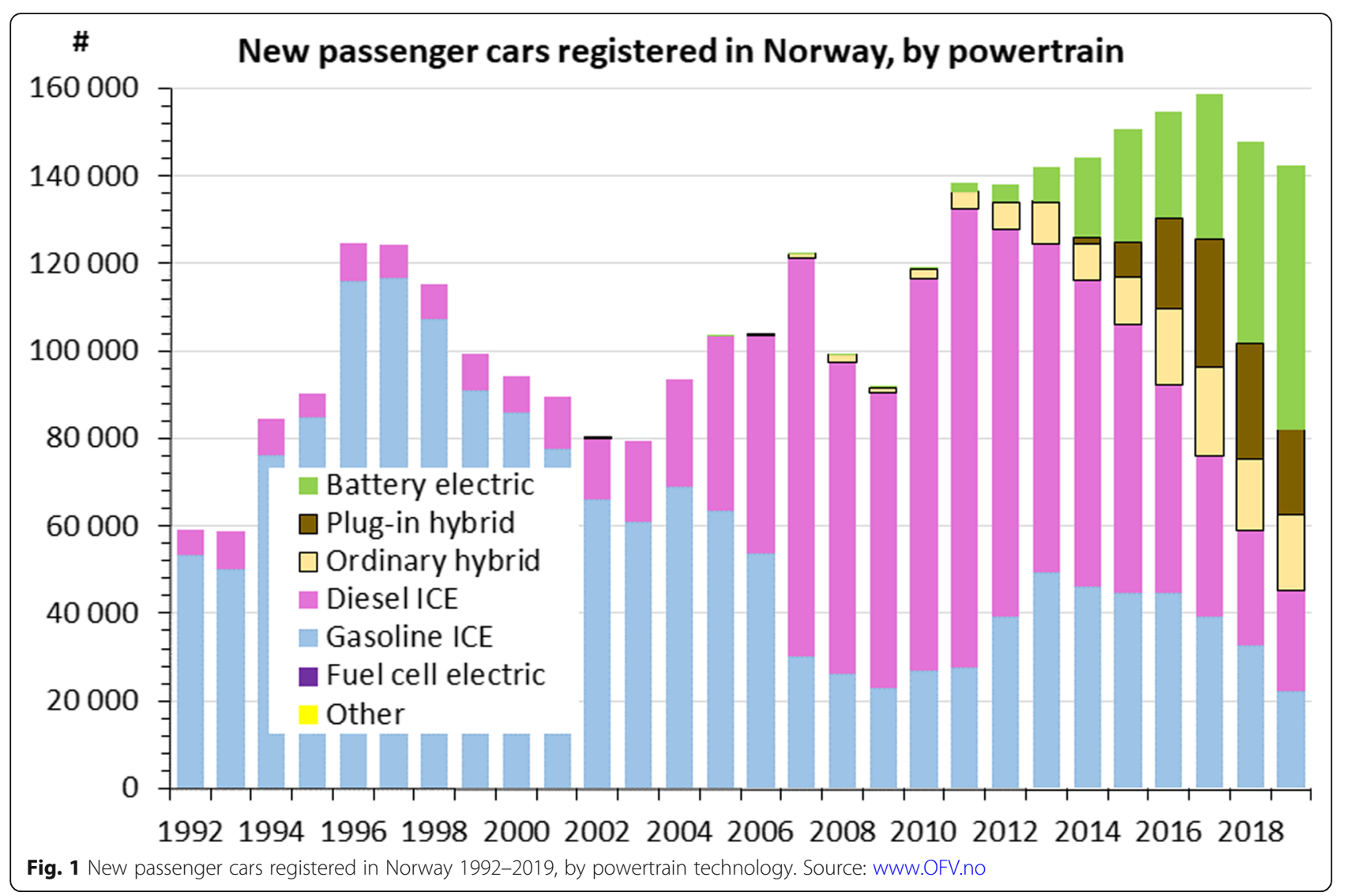

Berkovec and Rust [3], all of these relying on disaggregate discrete choice modeling.

An alternative approach consists in direct demand econometric modeling of aggregate vehicle miles traveled and fuel sales. Johansson and Schipper [43] decomposed the overall effect of fuel prices on fuel consumption into three factors: vehicle stock, mean annual mileage and mean energy intensity, all of which may be expected to vary in response to changes in the price of energy, and more so in the long term than in the short term. Based on aggregate (per capita) data for 12 OECD countries during 1973-92, they derive "best guesses" for the long run elasticities of the vehicle stock, the mean fuel intensity and the mean annual mileage with respect to the fuel price, given by $-0.1,-0.4$ and -0.2 , respectively. By implication, the long run elasticities of aggregate fuel demand and vehicle kilometers traveled (VKM) with respect to the fuel price are given by -0.7 and -0.3 , respectively.

More recently, and based on essentially the same conceptual decomposition, Odeck and Johansen [49] derive fuel and travel demand elasticities for Norway. The short and long run fuel demand elasticities are estimated at -0.26 and -0.36 , respectively, and the travel demand (VKM) elasticities at -0.11 and -0.24 . The rebound effect $[52,53]$ is estimated at $26 \%$, meaning that a $1 \%$ reduction in the fuel price gives rise to a $0.26 \%$ deterioration in the fuel efficiency and/or an equivalent increase in travel demand. $26 \%$ of the initial effect is, in other words, offset by behavioral adaptation.

Hössinger et al. [39] combine revealed (RP) and stated preference (SP) data to estimate fuel price elasticities for Austria. While most econometric studies are based on the often unsubstantiated assumption that price elasticities are constant over the potential range of variation, these authors allow for price elasticities to vary with the initial price level. Starting from a fuel price of $€ 1.50$ per liter, they derive an immediate elasticity of -0.116 , a one-year response of -0.185 , and a five-year elasticity of -0.245 . If the initial price is set at $€ 2.00$, the corresponding elasticities become $-0.158,-0.276$ and -0.321 , respectively. A $€ 4.00$ initial price results in elasticities as high as $-0.347,-0.656$ and -0.688 .

The idea that (the absolute value of) the fuel price elasticity increases with the initial price level makes theoretical and empirical sense. Results compatible with this have been derived by Dahl [9] and Fridstrøm [22], among others.

Obviously, the price elasticity of demand for fuel is also context dependent. It would be higher (in absolute value) whenever traveling by car has close substitutes, such as in a city with an efficient mass transit service. 
More generally, fuel demand would typically be more elastic in densely populated cities and countries than in rural communities or in suburbs characterized by extensive urban sprawl.

Meta-analyses and survey articles therefore exhibit a wide variety of elasticity estimates $[5,9,16,44]$. The mean elasticity derived from a meta-analysis cannot readily be assumed to hold for any particular city or country.

Moreover, meta-analyses are vulnerable to publication bias: Studies resulting in high and statistically significant elasticity estimates have a higher probability of being published and subsequently picked up by meta-analysts. Havranek [37] examines 110 studies of the short term gasoline price elasticity and 92 studies of the long term elasticity. The mean of the short term elasticities estimated is -0.227 , while the long term elasticities average -0.691 . When correcting for publication bias, Havranek [37] finds that both averages are roughly halved.

A particularly influential paper is the one by Berry, Levinsohn and Pakes [4] - henceforth BLP. They study the US automobile market relying on an aggregate panel data set that follows car models over all years they have been marketed during 1971-1992. Unlike most previous studies, they treat automobile prices as endogenous on account of unobserved product attributes. In their words,

"If producers know the values of the unobserved characteristics, [...] even though we [the analysts] do not, then prices are likely to be correlated with them. [...] products that face good substitutes will tend to have low markups, whereas other products will have high markups and thus high prices relative to cost."

If two cars of competing makes are similar, chances are that there is downward pressure on the price. Otherwise manufacturers and dealers may exploit the situation to ask for higher prices. Thus, BLP devise a set of instrumental variables based on each car model's similarity with other models. To estimate their model, BLP use a generalized method of moments (GMM) approach.

Verboven [56] studies product differentiation and price discrimination in the automobile market, relying on an aggregate data set covering 41 pairs of gasoline or diesel driven car models of a given make sold in Belgium, France or Italy during 1991-1994. Automobile buyers are assumed to trade off retail prices against future fuel expenditure, in such a way that buyers with a high expected mileage would tend to put less emphasis on the upfront cost of purchase and more emphasis on the fuel economy. These buyers might, e.g., prefer an expensive diesel car with a favorable fuel mileage over a cheaper gasoline-thirsty vehicle.
Like BLP, Verboven treats automobile retail prices as endogenous. Markups are inversely related to fuel and vehicle tax rates. Simple, ordinary regression estimates of the price coefficients would thus be biased towards zero. Verboven defines a set of instrumental variables based on the tax and fuel price differentials between gasoline and diesel vehicles, along with a 'performance' indicator summarizing the vehicles' horsepower, displacement and weight.

Verboven concludes that the choice between gasoline and diesel driven cars is to a large extent conditioned by the car owner's expected mileage, and that manufacturers exploit the car buyers' heterogeneous preferences to discriminate against those with a high willingness to pay for fuel savings. Fuel economic cars have higher markups.

Several alternative ways to handle the endogeneity problem, including certain 'instrument free' approaches, are reviewed by Zaefarian et al. [60].

Rather than considering vehicle acquisition and mileage as sequential behavioral variables, where one precedes and conditions the other, a conceptually more elegant formulation is offered by de Jong [10-12], who analyzes car ownership and use as jointly dependent household decisions within a rigorous microeconomic framework. The household decides to own a car if the utility derived from driving exceeds the utility achievable in the absence of car expenditure. The stronger the preference for high annual mileage, the larger is the probability that the household will choose to own a car.

Extending this framework so as to also model the choice of vehicle type or model simultaneously with the travel demand decisions, while taking account of price endogeneity and tax incidence, represents a major methodological challenge, but also a promising new vein of research. Relying on rich administrative data bases, some recent studies have come a long way towards modelling the complex, joint decision processes of vehicle choice and usage [7, 28-31, 42, 48].

\section{The Norwegian automobile market and electric vehicle incentives}

The rapid uptake of electric cars in the Norwegian market is explicable in terms of powerful fiscal and regulatory incentives $[19,20,23]$. The high share of battery and hybrid electric automobiles comes as a result of an enduring, no-nonsense government policy, consisting of ten different taxes and regulations of which zero exhaust emission vehicles (ZEVs), i.e. battery and fuel cell electric cars, are wholly or partially exempt:

1. Graduated, one-off registration tax, with ZEVs fully exempt 
2. Reregistration tax on second hand sales, with ZEVs fully exempt

3. Annual circulation (ownership) tax, with ZEVs fully exempt

4. Fuel tax, not applicable to ZEVs

5. Road toll, with ZEVs fully or partially exempt

6. Ferry fares, with strongly reduced rates for ZEVs

7. Public parking fees, often with full exemption for ZEVs and with free recharging

8. Income tax on private use of company cars, with lower rates for ZEVs

9. Bus lanes, open to ZEVs, although with some exceptions

10. Value added tax (VAT), with ZEVs fully exempt

\subsection{The one-off registration tax}

The probably most important incentive is the $\mathrm{CO}_{2}$-differentiated, one-off vehicle registration tax ('purchase tax'), payable upon first registration of any passenger car or light commercial vehicle with an internal combustion engine (ICE).

As of 2016, the purchase tax was the sum of four separate components. In Fig. 2, all of these four components are shown graphically, as functions of $10 \mathrm{~kg} \mathrm{curb}$ weight, $\mathrm{kW}$ ICE power, $g \mathrm{CO}_{2} / \mathrm{km}$ and $m g N O_{X} / \mathrm{km}$ type approval emission rates, respectively, each of them plotted along the same horizontal axis. Note that, as of 2016, the $\mathrm{CO}_{2}$ component is negative and hence deductible below $95 \mathrm{gCO}_{2} / \mathrm{km}$.

To fix ideas, consider a couple of examples. For a hypothetical car weighing $1500 \mathrm{~kg}$, with a $100 \mathrm{~kW}$ internal combustion engine (ICE) and type approval emission rates of $50 \mathrm{gCO}_{2} / \mathrm{km}$ and $50 \mathrm{mgNO}_{\mathrm{X}} / \mathrm{km}$, the purchase tax components in 2016 would sum to NOK $75,817+3768-41,347+2898=$ NOK 41,136 , corresponding to $€ 4400$ at the July 1, 2016 exchange rate.

As a second example, a car weighing $2000 \mathrm{~kg}$, with a $150 \mathrm{~kW}$ internal combustion engine (ICE) and type approval emission rates of $150 \mathrm{gCO}_{2} / \mathrm{km}$ and $50 \mathrm{mgNO}_{\mathrm{X}} /$ $\mathrm{km}$ would incur purchase tax components of NOK 172, 382 , NOK 27,315, NOK 61,628 and NOK 2898, summing to NOK 264,213 , or $€ 28,260$, i.e. a more than six times higher tax than in the previous example.

The convex weight, ICE power and $\mathrm{CO}_{2}$ components mean that heavy, powerful, gas guzzling cars are subject to a disproportionately higher purchase tax compared to smaller and leaner vehicles.

The minimum purchase tax in Norway is zero. Even if the negative $\mathrm{CO}_{2}$ component should be larger in absolute value than the sum of the three positive components, the

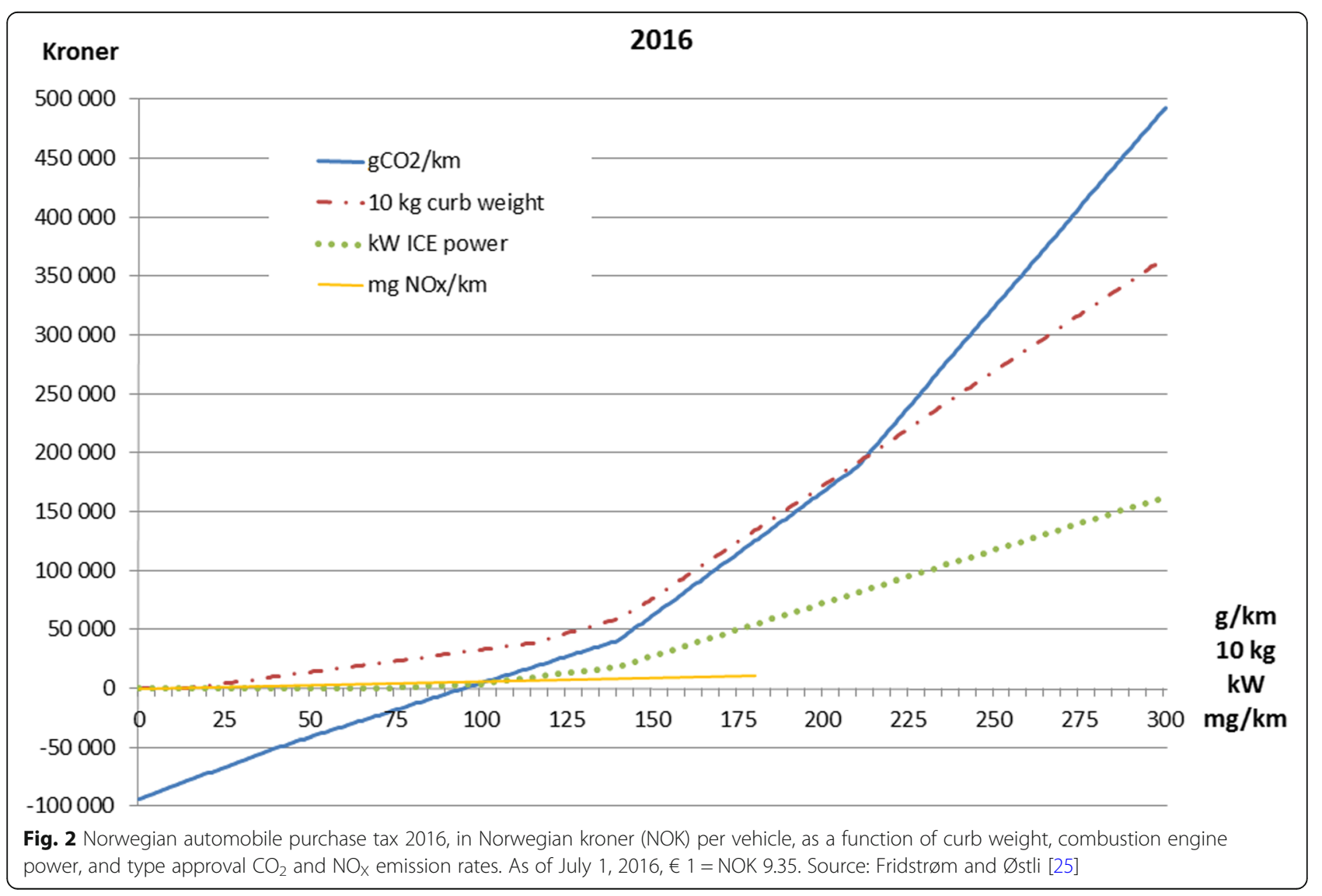


total purchase tax rate would not turn into a subsidy, as in the French bonus-malus system (see $[8,57]$ ).

Certain special tax breaks apply to plug-in hybrid vehicle (PHEVs). First of all, the effect of the electric motor does not count towards the power component of the purchase tax; only the combustion engine does. Secondly, as of 2016 the taxable curb weight of PHEVs was to be reduced by $26 \%$ prior to calculating the weight component. This essentially means that for PHEVs, every point on the red curve in Fig. 2 is shifted $35.1 \%$ to the right $($ since $1 /(1-0.26)=1.351)$.

For ordinary (non-plug-in) hybrid electric vehicles (HEVs), a weight 'rebate' of $10 \%$ applied in $2016 .{ }^{1}$

\subsection{The scope and value of Norwegian fiscal and regulatory incentives}

Particularly strong incentives apply to zero exhaust emission vehicles (ZEVs), be they battery or fuel cell electric. Not only are these vehicles entirely exempt of purchase tax, they are also, as of 2016, generally exempt of road toll and public parking charges. They benefit from strongly reduced ferry fares, lower annual ownership tax and lower income tax on the private use of company cars. Moreover, they are, with a few exceptions, allowed to travel in the bus lane and may be recharged for free in many public parking lots. Last, but not least, while ICE and hybrid cars are subject to a standard $25 \%$ value added tax (VAT) on the price exclusive of purchase tax, ZEVs, their batteries and their leasing contracts are exempt of VAT.

To get an idea of the scope of these incentives, it is helpful to have a look at the amount of tax revenues from ICE vehicles (Fig. 3). The annual revenue from registration, ownership, reregistration and fuel tax in 2016 was 52.8 billion Norwegian kroner (NOK), or $€$ 5.647 billion, corresponding to around $€ 1130$ per capita. Automobile taxes are an important source of government revenue in Norway.

None of these taxes applied to ZEVs. Thus, the falling revenue from purchase tax since 2012 is due primarily to the increasing flow of new ZEVs (see Fig. 1). The revenue from ownership tax and fuel tax will fall more slowly, at a pace determined by the penetration of ZEVs in the automobile stock.

The one-off registration tax (purchase tax) alone provided a fiscal revenue of NOK 16.748 billion in 2016 . Some $70 \%$ of this revenue, corresponding roughly to $€$ 1.25 billion, was levied on passenger cars (the rest being attributable to light commercial vehicles, motorcycles,

\footnotetext{
${ }^{1}$ This rebate has since been abolished, as has also the entire ICE power component. As of 2019, the weight rebate for PHEVs has been lowered to $23 \%$ and made contingent upon an at least $50 \mathrm{~km}$ allelectric range. For PHEVs with an all-electric range of $r<50 \mathrm{~km}$, the rebate is set at $23 \cdot r / 50 \%$.
}

etc.). As averaged over all passenger cars equipped with an ICE first registered in Norway in 2016, the purchase tax amounted to around NOK $83,000=€ 8880$ per vehicle.

The aggregate revenue from road use and $\mathrm{CO}_{2}$ tax on fuel was NOK 22.7 billion in 2016. The fuel tax rate was NOK 5.96 per liter of gasoline and NOK 4.56 per liter of diesel, corresponding to $€ 0.637$ and $€ 0.488$ per liter, respectively, or US\$ 2.71 and US\$ 2.08 per gallon. Norwegian fuel taxes are radically higher than in the US, but only slightly higher than the European average.

Road toll represents another NOK 10 billion or so in annual public revenue, with zero or little contributions from ZEVs. There are about 60 toll plazas or cordons in operation in Norway, all of them with the purpose of funding road investments or urban transit.

In its notification to the EFTA Surveillance Authority of November 6, 2017, the Norwegian Royal Ministry of Finance [51] estimated the revenue loss from the ZEVs' exemption from the various vehicle taxes, toll and ferry charges at appr. NOK 2 billion in 2017. The VAT exemption is found to represent a revenue loss of about NOK 3.2 billion in 2017. Avoided fuel tax would represent another NOK 1 billion or so.

The value of the non-pecuniary incentives, such as the ZEVs' access to the bus lanes, depends on local conditions, e.g. if there is congestion that ZEV drivers can avoid. In a survey of battery electric vehicle (BEV) owners, Figenbaum and Kolbenstvedt [21] estimate the mean value of the time savings due to bus lane access at NOK 4498 per BEV owner per year. Multiplying this figure by the approximately $97,400 \mathrm{ZEVs}$ present in the Norwegian car fleet at year-end 2016, we arrive at an aggregate annual figure of NOK 438 million $=€ 46.8$ million.

Thus, taken together, the value of the tax breaks and regulatory privileges benefiting ZEV owners is of the order of NOK 6.6 billion per annum, or around $€ 700$ million. Dividing this figure by the stock of ZEVs at year-end 2016, we arrive at a value of $€ 7250$ per ZEV per annum $[23,24]$.

\subsection{Subsidies}

Contrary to common belief, almost no cash subsidies are being paid out in support of electric cars in Norway. With two minor exceptions, all of the Norwegian incentives take the form of taxes and regulations affecting vehicles equipped with an ICE, with full or partial exemptions for battery and fuel cell electric vehicles, as set out in the previous section.

The two exceptions are (i) the public support for electric vehicle charging stations and hydrogen refueling infrastructure, administered through the Enova government agency, and (ii) local governments footing the 


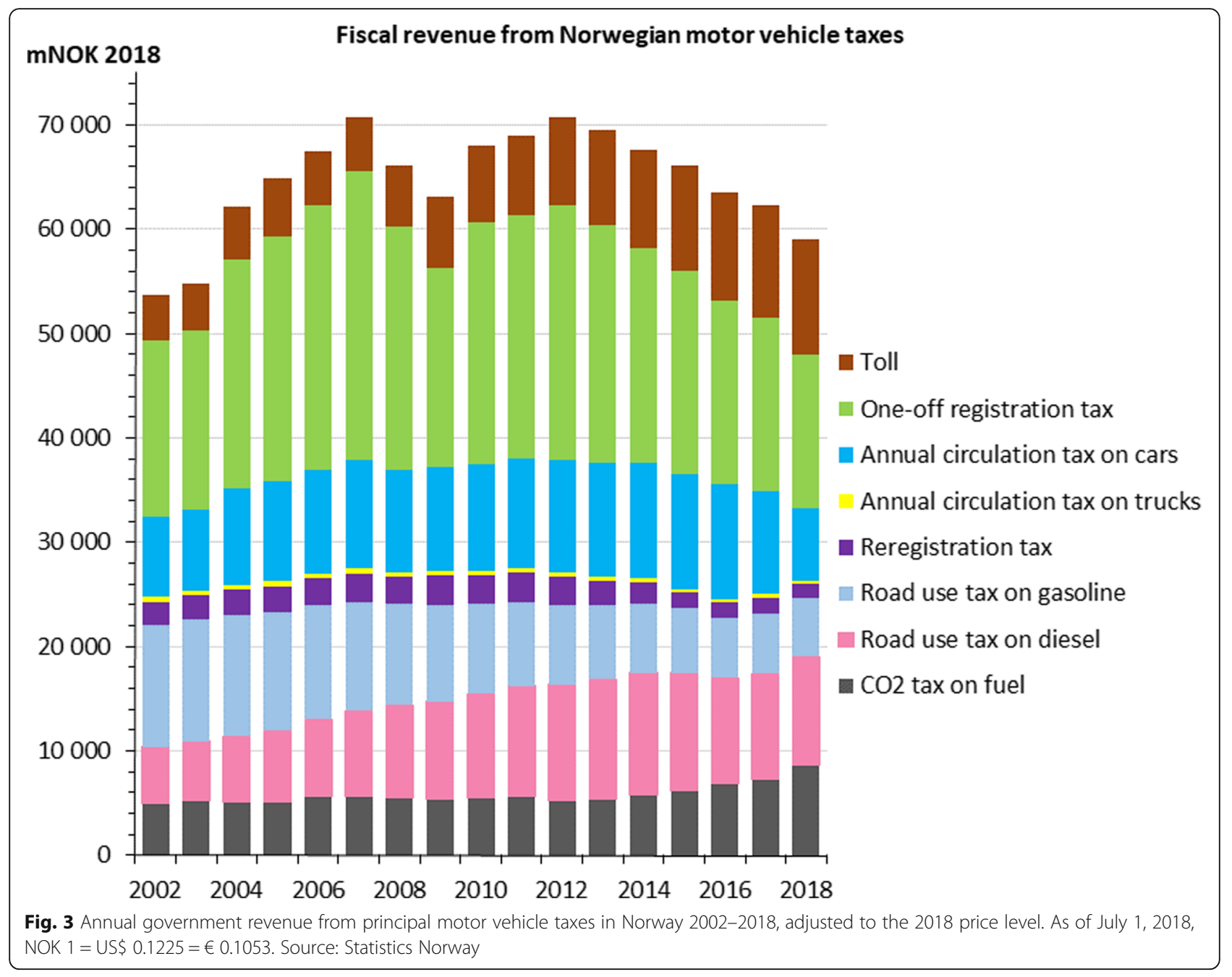

electricity bill at public parking lots (cf. item 7 in the above list). These are costs covered by the taxpayers, that would otherwise be incurred by the users of electric cars themselves.

Compared to the automobile tax revenues, the scope of the Enova subsidies is quite modest. A mere NOK 11 million, or approximately $€ 1.18$ million, was granted in support of roadside charging stations in 2017, according to Enova's annual report ([15]: 27). Another NOK 30 million was granted for hydrogen refueling infrastructure.

The electricity bill at public parking lots is not large either, on account of Norway's generally low prices of electricity and the fact that most BEV owners routinely recharge their vehicle at home.

\subsection{The shifting market for diesel cars}

With the introduction, in 2007, of the technology neutral $\mathrm{CO}_{2}$ component of the purchase tax, instead of the previous, fuel-specific displacement component, the demand for diesel driven passenger cars in Norway increased steeply (Fig. 1). Since the $\mathrm{CO}_{2}$ emissions rate is directly proportional to the per $\mathrm{km}$ fuel consumption, and since the diesel engine is more energy efficient than the gasoline engine, the relative after-tax prices of gasoline versus diesel driven cars changed in favor of diesel vehicles, making these vehicles considerably more popular with the buyers. Adding to this trend was the car users' steadily improving impression of the diesel engine as more or less equivalent to the gasoline engine in terms of thrust, user friendliness and technological maturity. The demand for new diesel cars continued to grow until 2011, when their market share reached $75.7 \%$.

A watershed may seem to have occurred with the unusual and lingering atmospheric contamination in the city of Bergen in January 2010 - Bergen's 'winter of discontent' [54]. Diesel automobiles were singled out as a major source of pollution. Following this incident, the nitrogen oxide $\left(\mathrm{NO}_{\mathrm{X}}\right)$ emissions from 
diesel vehicles received steadily more attention in Norwegian public discourse. In 2011, the EFTA Surveillance Authority, the agency in charge of enforcing EU regulations in Norway, Iceland and Liechtenstein, alerted the Norwegian government of multiple cases in which Norwegian cities had exceeded the regulated limit values for certain pollutants in ambient air. In 2013, formal proceedings against Norway were opened at the EFTA Court, which concluded, on October 2, 2015, that the limit values for sulphur dioxide $\left(\mathrm{SO}_{2}\right)$, particulate matter $\left(\mathrm{PM}_{10}\right)$ and/or nitrogen dioxide $\left(\mathrm{NO}_{2}\right)$ in ambient air in certain cities had been surpassed on several occasions during the years 2009 to 2012, and hence that

'the Kingdom of Norway has failed to fulfil its obligations arising under the [...] Agreement on the European Economic Area (Directive 2008/50/EC of the European Parliament and of the Council of 21 May 2008 on ambient air quality and cleaner air for Europe)' [14].

Adding to this ruling were the multiple reports from Norwegian scientists about the large gap between real-world and laboratory measured $\mathrm{NO}_{\mathrm{X}}$ emissions from diesel driven passenger cars [32, 33, 58]. Thus, well before the Volkswagen scandal broke in 2015, Norwegian legislators and policy makers had been alerted to the problem. Already in 2011, the first hints were aired about the need to limit the use of diesel cars in urban areas. New legislation has since opened the door on temporary or permanent local restrictions on diesel vehicle use. Local governments may now ban diesel vehicles from entering the inner city under highly polluted atmospheric conditions. Since October 2017, diesel cars are subject to an augmented cordon toll rate in the city of Oslo. These restrictions, and the uncertainty surrounding their possible future enforcement and extension, have deterred many urban car buyers from choosing a diesel vehicle, bringing their market share down to $16.0 \%$ in 2019. Most probably, the diesel engine's predicament has meant a blessing to the electric motor, helping BEVs to an accelerated market uptake.

\subsection{A European perspective}

European countries apply a variety of automobile taxation systems $[13,35,57]$. Although most countries in EU and EFTA do levy some kind of purchase or registration tax, their structures and levels differ considerably. Some countries grant subsidies and bonuses to buyers of BEVs and low emission cars. Other countries apply whole or partial tax exemptions for battery, fuel cell and/or plug-in hybrid electric vehicles. The $\mathrm{CO}_{2}$ abatement effects of these tax breaks depend strongly on how heavily taxed conventional vehicles are in the first place.

Most countries in EU and EFTA levy an excise tax on fossil fuel, with per liter rates that typically add around $100 \%$ on top of the pre-tax value.

As its main pillar of climate policy within transportation, the European Union [17] has mandated maximum $\mathrm{CO}_{2}$ emission targets for new passenger cars sold each year from 2020 through 2030. The overall target in 2020 through 2024 is $95 \mathrm{gCO}_{2} / \mathrm{km}$, as measured by the type approval NEDC laboratory trial and averaged over all vehicles brought to the EU market. More lenient standards apply to manufacturers producing heavier than average vehicles. The regulation applies EEA-wide. ${ }^{2}$

To meet the targets, automobile manufacturers are introducing a widening range of battery and plug-in hybrid electric vehicles (BEVs and PHEVs). Special accounting rules make sure that vehicles with a type approval $\mathrm{CO}_{2}$ emission below $50 \mathrm{gCO}_{2} / \mathrm{km}$ give rise to 'super-credits' towards the EU target for 2020, 2021 and 2022. Manufacturers failing to meet their targets will incur heavy penalties.

But between 2016 and 2019, the emission rates of new passenger cars have moved in the wrong direction. According to the European Environmental Agency, the average $\mathrm{CO}_{2}$ emissions from new passenger cars in the EU was $118.1 \mathrm{gCO}_{2} / \mathrm{km}$ in 2016, 118.5 in 2017, 120.8 in 2018 and 122.4 in 2019, before taking account of supercredits.

This contrasts sharply with the development in Norway, where type approval emission rates have come down sharply, to a mean of $60 \mathrm{gCO}_{2} / \mathrm{km}$ in 2019 (Fig. 4).

These two disparate developments give rise to an intriguing question: Could the Norwegian recipe be generalized - or replicated by other European nations? The answer is a conditional yes.

As noted above, only a negligible share of the Norwegian incentives is made up by subsidies. In essence, the policy consists in taxing ICE vehicles. In every EEA country except Denmark, introducing a Norwegian style set of fiscal incentives in place of the present automobile taxation and subsidization regime would probably bring massive amounts of new revenue into the public treasury [23]. Public finance constraints are, in other words, no argument against the Norwegian incentives.

But the introduction of electric vehicles in Norway is facilitated by a number of circumstances not necessarily present in EU member states:

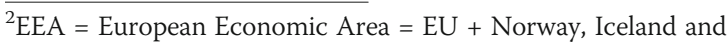
Liechtenstein. 


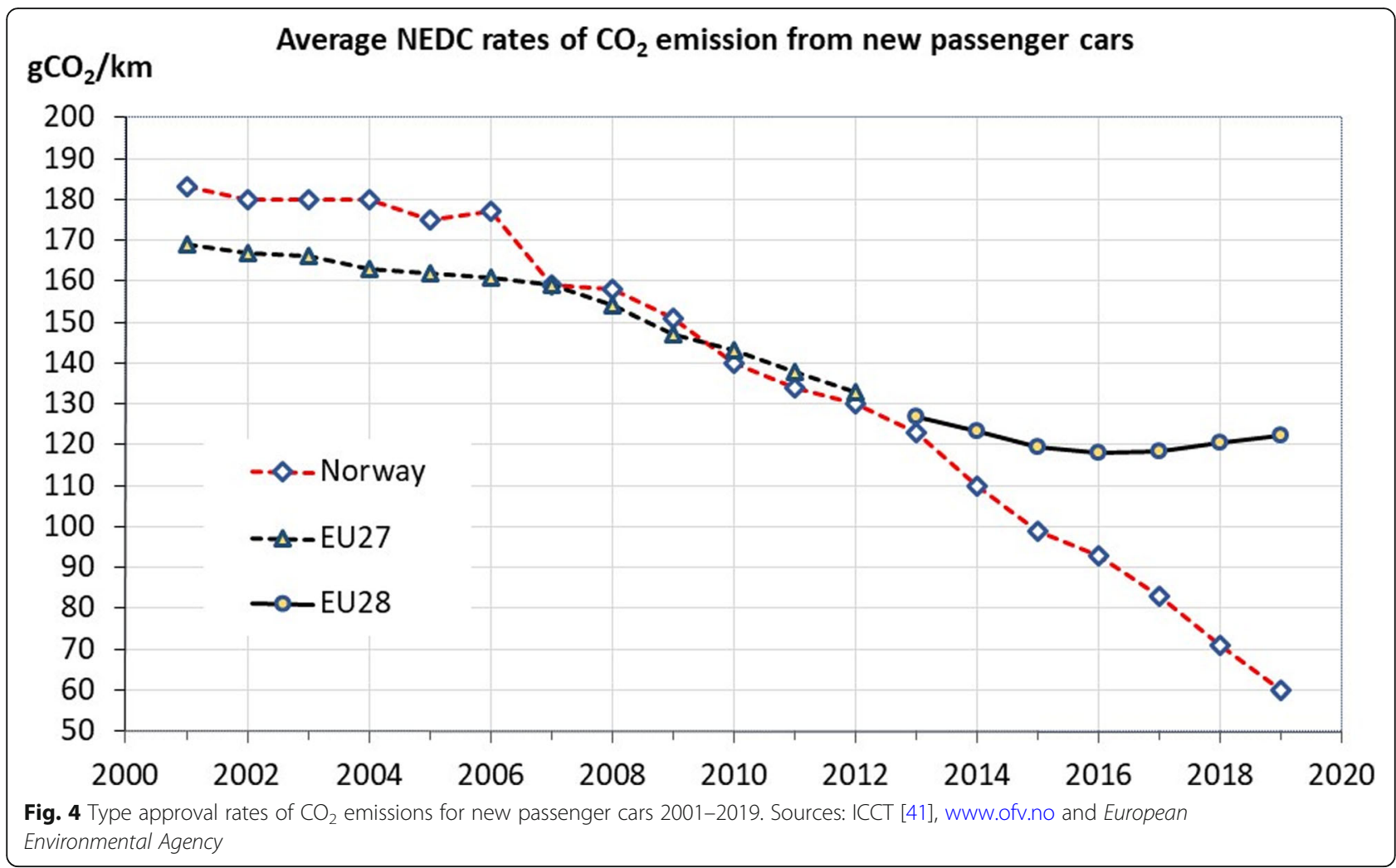

1. The electricity supply is based on hydropower and quite abundant. The per capita output is more than three times larger than in Germany. The consumer price level is roughly three times lower, typically around $€ 0.10$ per $\mathrm{kWh}$.

2. The local grids are strong, as most office buildings and homes are heated by electricity, and winters are cold. With the introduction of smart demand response systems, the grids will be capable of accommodating large-scale vehicle recharging through outlets in private homes.

3. A relatively large share of the population live in detached houses with a driveway, garage or other designated parking, where a private charging point can easily be mounted.

4. There is ample space. Fast charging stations can be set up along most major highways.

5. Toll roads and ferry crossings are almost ubiquitous. By exempting BEVs from toll and ferry fares, forceful incentives are created.

6. Roads are slow. This improves the driving range and makes it less important. Going by car from the Norwegian capital to any one of the other three major cities takes about $7 \mathrm{~h}$, for an about $500 \mathrm{~km}$ distance. On a 7-h trip, most people do not mind a 30 -min break for recharging etc. On
European motorways, the same distance might be covered in about $4 \mathrm{~h}$, turning a 30 -min inevitable stop into a nuisance.

7. Norway has no domestic auto industry that might lobby against ICE vehicle taxation.

\section{Modeling approach}

To derive elasticities of demand and other market response functions, a behavioral model of automobile choice is helpful. We have thus estimated a nested logit model ([1]: 285) based on a disaggregate data set covering virtually all new passenger car purchases in Norway between January 2002 and October 2016. Almost 1.8 million individual car transactions are included in the data set, which has been organized into 30,175 rows, each describing a given model variant of which at least one specimen was sold in a given year. The vehicle attributes specified for each model variant include the list price, registration tax, value added tax (VAT), length, width, powertrain, ICE type approval fuel consumption and $\mathrm{CO}_{2}$ emissions per $\mathrm{km}, \mathrm{BEV}$ or PHEV electric range, traction (rear-, front- or 4wheel), number of doors and seats, transmission, body style, and make.

On average, there were 2012 different models variants offered annually in the Norwegian market during 2002-2016. By way of illustration, we provide in the 


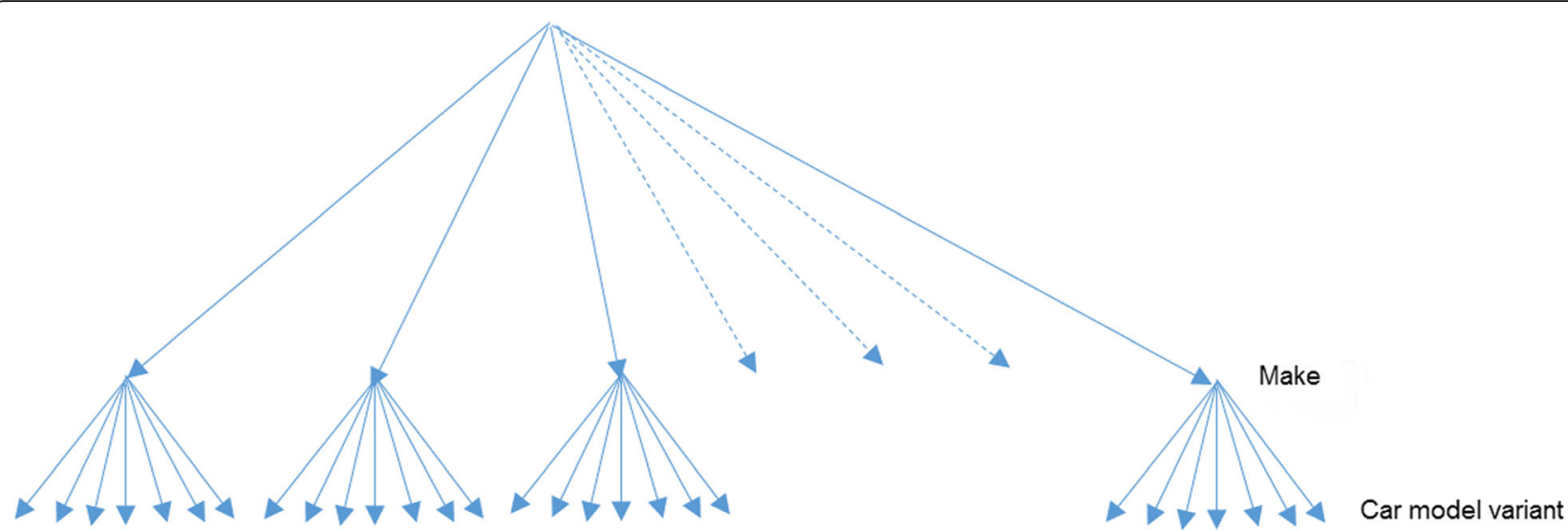

Fig. 5 Nest structure in discrete choice automobile purchase model. Source: Østli et al. [50]

Appendix a couple of scatterplots where the retail price of each vehicle model variant is plotted against the price exclusive of tax or against the calculated energy costs.

The upper nests of the model are defined as makes (brands), while the lower level alternatives consist of the model variants offered by each manufacturer (Fig. 5). Several rounds of trial-and-error were performed, on a previous data set, to arrive at a nest structure compatible with a priori theoretical constraints concerning the utility scale parameters [50]. In our model, these are all larger than unity.

According to this structure, the probability of choosing a given vehicle model variant $i$ of make $j$ is the product of the probability of choosing make $j$ and the conditional probability of choosing model variant $i$ given the set available within make $j$. The mathematical formula for calculating the choice probability in year $t$ can be stated as:

$$
\begin{aligned}
P_{t}(\text { variant }=i)= & P_{t}(\text { variant }=i \mid \text { make }=j) \\
& \cdot P_{t}(\text { make }=j)
\end{aligned}
$$

If we denote by $M_{t j}$ the set of model variants of make $j$ available in year $t$, the two factors in (1) can be specified as

$$
\begin{gathered}
P_{t}(\text { variant }=i \mid \text { make }=j) \\
=\frac{\exp \left(\mu_{j} V_{i j}\right)}{\sum_{h \in M_{t j}} \exp \left(\mu_{j} V_{h j}\right)},(t=2002,2003, \ldots, 2016) \\
P_{t}(\text { make }=j)=\frac{\exp \left(\frac{1}{\mu_{j}} \ln \left[\sum_{i \in M_{t j}} \exp \left(\mu_{j} V_{i j}\right)\right]\right)}{\sum_{k=1}^{19} \exp \left(\frac{1}{\mu_{k}} \ln \left[\sum_{i \in M_{t k}} \exp \left(\mu_{k} V_{i k}\right)\right]\right)} \\
(t=2002,2003, \ldots, 2016)
\end{gathered}
$$

In these two expressions $\mu_{j}$ denotes the estimated scale parameter for each make in the lower nest. When normalizing the upper scale parameter to unity, these lower scale parameters are restricted to be larger than unity. The indirect utility function specified for each individual vehicle model variant $i$ of make $j$, denoted $V_{i j}$, is specified as a linear combination of coefficients and explanatory variables:

$$
V_{i j}=\sum_{k} \beta_{k} x_{i j k}+\gamma_{j} .
$$

Here, the explanatory variables $x_{i j k}$ are vehicle attributes. The $\gamma_{j}$ are make-specific constants, estimated as the coefficients of a set of dummy variables $-z_{i j}$, say - equal to one if and only if model variant $i$ belongs to make $j$ (see Table 1 for details). Note that the $\beta_{k}$ coefficients are not indexed by $i$ or $j$ - they are all generic, i. e. identical across vehicle model variants and makes.

As analysts, we do not have full information about the indirect utility generated by each vehicle model variant. Following common practice, we assume that the observable utility $U_{i j}$ (say) consists of the systematic term $V_{i j}$ and some random disturbance term $e_{i j}$, i. e.

$$
U_{i j}=V_{i j}+e_{i j}
$$

where the $e_{i j}$ are independent and identically Gumbel distributed random variables with scale parameters $\mu_{j}$ ([1]: 287).

Although the differences between certain car model variants are miniscule, they are all defined as separate units in the data set. The model contains 81 parameters, of which 19 are scale (log-sum) parameters characterizing the lower nests.

Although, at the upper level, model variants are grouped together into makes, the discrete choice model contains no bulkheads separating different market segments from each other. Each model variant competes, in 
Table 1 Nested logit model of automobile purchase. Coefficient estimates and standard errors. Source: Fridstrøm and Østli [25]

\begin{tabular}{l} 
Variable description \\
\hline Continuous variables \\
Log of size in square meters (length x width) \\
List price (100 kNOK 2016) \\
Net present value of energy outlay (100 kNOK \\
Non-tax share of list price \\
Square root of BEV electric range ( $\mathrm{km}$ ) \\
Square root of PHEV electric range (km) \\
Diesel trend (log of years since 1995) \\
Dummy variables for vehicle attributes \\
Diesel ICE 2012 \\
Diesel ICE 2013 \\
Diesel ICE 2014 \\
Diesel ICE 2015 \\
Diesel ICE 2016 \\
Rear-wheel traction (reference: 4-wheel) \\
Front-wheel traction (reference: 4-wheel) \\
HEV (reference: gasoline ICE) \\
PHEV (reference: gasoline ICE) \\
Diesel ICE (reference: gasoline ICE) \\
BEV (reference: gasoline ICE) \\
At least 5 doors \\
Stick shift (reference: automatic shift)
\end{tabular}

Dummy variables for body style (reference: compact)

Convertible
Coupé
Panel van
Minivan
Pick-up truck
Sedan
Station wagon
Sport-Utility Vehicle (SUV)

Dummy variables for make (reference: all other makes)

$\begin{array}{ll}\text { Volkswagen } & \text { Cvolkswagen } \\ \text { Toyota } & \text { Ctoyota } \\ \text { Ford } & \text { Cford } \\ \text { Volvo } & \text { Cvolvo } \\ \text { Peugeot } & \text { Cpeugeot } \\ \text { Audi } & \text { Caudi } \\ \text { BMW } & \text { Cbmw } \\ \text { Nissan } & \text { Cnissan } \\ \text { Skoda } & \text { Cskoda } \\ \text { Opel } & \text { Copel } \\ \text { Mercedes } & \text { Cmercedes } \\ \text { Mitsubishi } & \text { Cmitsubishi } \\ \text { Mazda } & \text { Cmazda } \\ \text { Hyundai } & \text { Chyundai }\end{array}$

\begin{tabular}{|c|c|c|}
\hline Size & 2.520 & 0.0150 \\
\hline Price & -0.203 & 0.0012 \\
\hline Energycost & -0.331 & 0.0031 \\
\hline Resourcecostshare & 3.320 & 0.0212 \\
\hline BEVrange & 0.148 & 0.0027 \\
\hline PHEVrange & 0.090 & 0.0026 \\
\hline Dieseltrend & 0.769 & 0.0056 \\
\hline CDiesel12 & -0.382 & 0.0037 \\
\hline CDiesel13 & -0.520 & 0.0041 \\
\hline CDiesel14 & -0.528 & 0.0043 \\
\hline CDiesel15 & -0.721 & 0.0052 \\
\hline CDiesel16 & -0.824 & 0.0059 \\
\hline CRearwheel & -0.499 & 0.0038 \\
\hline CFrontwheel & -0.524 & 0.0031 \\
\hline CHybrid & -0.036 & 0.0027 \\
\hline CPlugin & -0.920 & 0.0186 \\
\hline CDiesel & -1.870 & 0.0140 \\
\hline CElectric & -2.500 & 0.0373 \\
\hline CFiveormoredoors & 0.615 & 0.0041 \\
\hline CManual & -0.123 & 0.0010 \\
\hline CCartype2 & 0.164 & 0.0051 \\
\hline CCartype4 & -0.081 & 0.0047 \\
\hline CCartype5 & -0.600 & 0.0079 \\
\hline CCartype6 & -0.065 & 0.0014 \\
\hline CCartype7 & -0.468 & 0.0413 \\
\hline CCartype8 & 0.123 & 0.0028 \\
\hline CCartype9 & 0.021 & 0.0010 \\
\hline CCartype10 & 0.387 & 0.0025 \\
\hline Cvolkswagen & 2.920 & 0.0231 \\
\hline Ctoyota & 2.910 & 0.0236 \\
\hline Cford & 1.680 & 0.0227 \\
\hline Cvolvo & 2.660 & 0.0250 \\
\hline Cpeugeot & 1.740 & 0.0238 \\
\hline Caudi & 1.930 & 0.0241 \\
\hline $\mathrm{Cbmw}$ & 1.300 & 0.0231 \\
\hline Cnissan & 1.300 & 0.0229 \\
\hline Cskoda & 1.730 & 0.0243 \\
\hline Copel & 0.939 & 0.0259 \\
\hline Cmercedes & 0.559 & 0.0253 \\
\hline Cmitsubishi & 1.600 & 0.0243 \\
\hline Cmazda & 1.780 & 0.0252 \\
\hline Chyundai & -0.204 & 0.0352 \\
\hline
\end{tabular}


Table 1 Nested logit model of automobile purchase. Coefficient estimates and standard errors. Source: Fridstrøm and Østli [25] (Continued)

\begin{tabular}{|c|c|c|c|}
\hline Variable description & Variable name & Coefficient & Standard error \\
\hline Suzuki & Csuzuki & 0.903 & 0.0262 \\
\hline Subaru & Csubaru & 0.954 & 0.0272 \\
\hline Honda & Chonda & 1.430 & 0.0257 \\
\hline Citroën & Ccitroen & 0.745 & 0.0268 \\
\hline Kia & Ckia & 0.490 & 0.0104 \\
\hline Renault & Crenault & 0.041 & 0.0098 \\
\hline Mini & Cmini & -0.121 & 0.0120 \\
\hline Fiat & Cfiat & 0.021 & 0.0121 \\
\hline Landrover & Clandrover & 0.209 & 0.0122 \\
\hline Lexus & Clexus & 1.000 & 0.0148 \\
\hline Chevrolet & Cchevrolet & -0.067 & 0.0144 \\
\hline Daihatsu & Cdaihatsu & -0.042 & 0.0155 \\
\hline Alfa Romeo & Calfaromeo & -0.211 & 0.0159 \\
\hline Porsche & Cporsche & 1.020 & 0.0176 \\
\hline Jeep & Cjeep & 0.099 & 0.0176 \\
\hline Jaguar & Cjaguar & -0.124 & 0.0204 \\
\hline Seat & Cseat & -0.515 & 0.0215 \\
\hline Smart & Csmart & -0.158 & 0.0233 \\
\hline Tesla & Ctesla & -0.595 & 0.0254 \\
\hline Saab & Csaab & 1.030 & 0.0119 \\
\hline \multicolumn{4}{|l|}{ Scale parameters for make } \\
\hline Volkswagen & muvolkswagen & 3.070 & 0.0184 \\
\hline Toyota & mutoyota & 2.820 & 0.0171 \\
\hline Ford & muford & 2.210 & 0.0143 \\
\hline Volvo & muvolvo & 3.240 & 0.0204 \\
\hline Peugeot & mupeugeot & 2.500 & 0.0175 \\
\hline Audi & muaudi & 2.710 & 0.0175 \\
\hline BMW & mubmw & 2.120 & 0.0134 \\
\hline Nissan & munissan & 1.970 & 0.0131 \\
\hline Skoda & muskoda & 2.960 & 0.0228 \\
\hline Opel & muopel & 1.910 & 0.0155 \\
\hline Mercedes & mumercedes & 1.580 & 0.0114 \\
\hline Mitsubishi & mumitsubishi & 2.460 & 0.0172 \\
\hline Mazda & mumazda & 2.920 & 0.0217 \\
\hline Hyundai & muhyundai & 1.260 & 0.0135 \\
\hline Suzuki & musuzuki & 1.850 & 0.0175 \\
\hline Subaru & musubaru & 1.900 & 0.0193 \\
\hline Honda & muhonda & 2.470 & 0.0206 \\
\hline Citroën & mucitroen & 2.090 & 0.0196 \\
\hline Other makes & muother & 1.480 & 0.0102 \\
\hline \multicolumn{4}{|l|}{ General } \\
\hline \# of parameters & k & 81 & \\
\hline \# of observation units & $\mathrm{n}$ & 30,175 & \\
\hline Initial log-likelihood & $\mathrm{L}_{0}$ & $-13,587,325$ & \\
\hline Final log-likelihood & $\mathrm{L}_{1}$ & $-12,368,837$ & \\
\hline Goodness-of-fit measure & Rho bar & 0.09 & \\
\hline
\end{tabular}


principle, with all other variants, although the degree of substitution will typically be larger within the respective nests than between them.

The model essentially distinguishes between five energy technologies (powertrains):

- Gasoline internal combustion engine (ICE) vehicles

- Diesel ICE vehicles

- Ordinary (non-plug-in) hybrid electric vehicles (HEVs)

- Plug-in hybrid electric vehicles (PHEVs)

- Battery electric vehicles (BEVs)

Although hydrogen fuel cell electric vehicles (FCEVs) were also present in the Norwegian market in 2016, with 23 vehicles sold, corresponding to a $0.015 \%$ market share, information on this energy technology is presently too scant to allow for demand modeling. Hence, FCEVs have been excluded from our data set. The same applies to cars running on liquefied petroleum gas (LPG) or compressed natural gas (CNG), of which there are almost none in the Norwegian automobile fleet. Also excluded are a small number of atypical, minibus-like passenger cars with 8 or 9 seats, as well as a few uncommon cars for which list price information was inaccessible.

Taken together, $99.1 \%$ of the new passenger cars registered between January 2002 and October 2016 are included in data set.

As far as we know, our model differs from all other automobile choice models in the scientific literature in relying exclusively on vehicle data. Our unit of observation is a car model variant, not a household or individual. No information is available on vehicle owners or buyers. Thus the utility functions of the nested logit model contain vehicle attributes only. Dispensing with information on the vehicle owners or buyers amounts to a massive simplification, which allows us to represent the vehicles themselves in a maximally detailed and disaggregate way.

Among the limitations following from our setup is the lack of vehicle mileage data. No information is available to us on the life expectancy, durability or maintenance costs of each individual model variant. Yet such information is probably available, albeit at an informal level, to the car buyers, conditioning their choices. As noted in Section 2, households with a large anticipated annual driving distance may tend to choose differently from those with a more limited car use demand. More importantly, families affected by a toll cordon or a ferry fare on their daily commute may be tempted to choose a vehicle that is exempt of such fees. In congested urban areas, BEV access to the bus lane is another important enticement.
The pros and cons of our modeling approach are discussed in more detail in Section 6.

\section{Results}

The model has been estimated by the maximum likelihood method as coded in the Biogeme Python software [25]. Detailed estimation results are reported in Table 1. All estimates have the expected sign. All but two parameter estimates of little consequence (the dummy coefficients of makes Fiat and Daihatsu) are significantly different from zero with a $p$-value smaller than 0.001 . In most cases, the standard error is less than $1 \%$ of the point estimate, implying exceptionally narrow confidence intervals for the coefficients.

\subsection{Direct and cross price elasticities of demand for automobiles}

The model provides imputed (fitted) values for the probabilities of choosing any one car model variant in any year from 2002 to 2016. Through counterfactual simulation and sample enumeration ([1]: 146-148), the model can be used to simulate a wide variety of hypothetical changes in the independent variables. In this paper, we focus on the effects of changes in vehicle or energy prices, as evaluated in our last year of observation 2016.

To derive, e.g., the direct and cross elasticities of demand with respect to the prices of gasoline cars, we simulate a $10 \%$ uniform change in the list prices of all gasoline cars and recalculate the predicted market shares of all automobile model variants, regardless of powertrain. By summing through the 2016 sample, we obtain new aggregate market shares for each energy technology. By dividing the percentage changes in these aggregate market shares by 10 , we obtain a measure of the market response to a $1 \%$ price change for gasoline cars, i.e. the own and cross price (arc) elasticities.

Similar counterfactual simulations are repeated with respect to the prices of BEVs, PHEVs, HEVs and diesel driven cars. Results are shown in Fig. 6.

The direct (own-price) elasticity of demand for gasoline cars is calculated at -1.08 . That is, in the event of a uniform $10 \%$ increase in the prices of gasoline cars, the number of new gasoline cars sold would shrink by $10.8 \%$, assuming all other prices to be constant.

The cross price elasticity of demand for diesel cars is estimated at 0.51 . That is, in the event of a uniform $10 \%$ increase in the prices of gasoline cars, the number of new diesel cars sold would go up by $5.1 \%$.

The cross price elasticities of demand for battery electric cars (BEVs), plug-in hybrid electric cars (PHEVs) and ordinary hybrid electric cars (HEVs) with respect to the price of gasoline cars are estimated at $0.36,0.43$ and 0.38 , respectively (light blue bars in Fig. 6). 


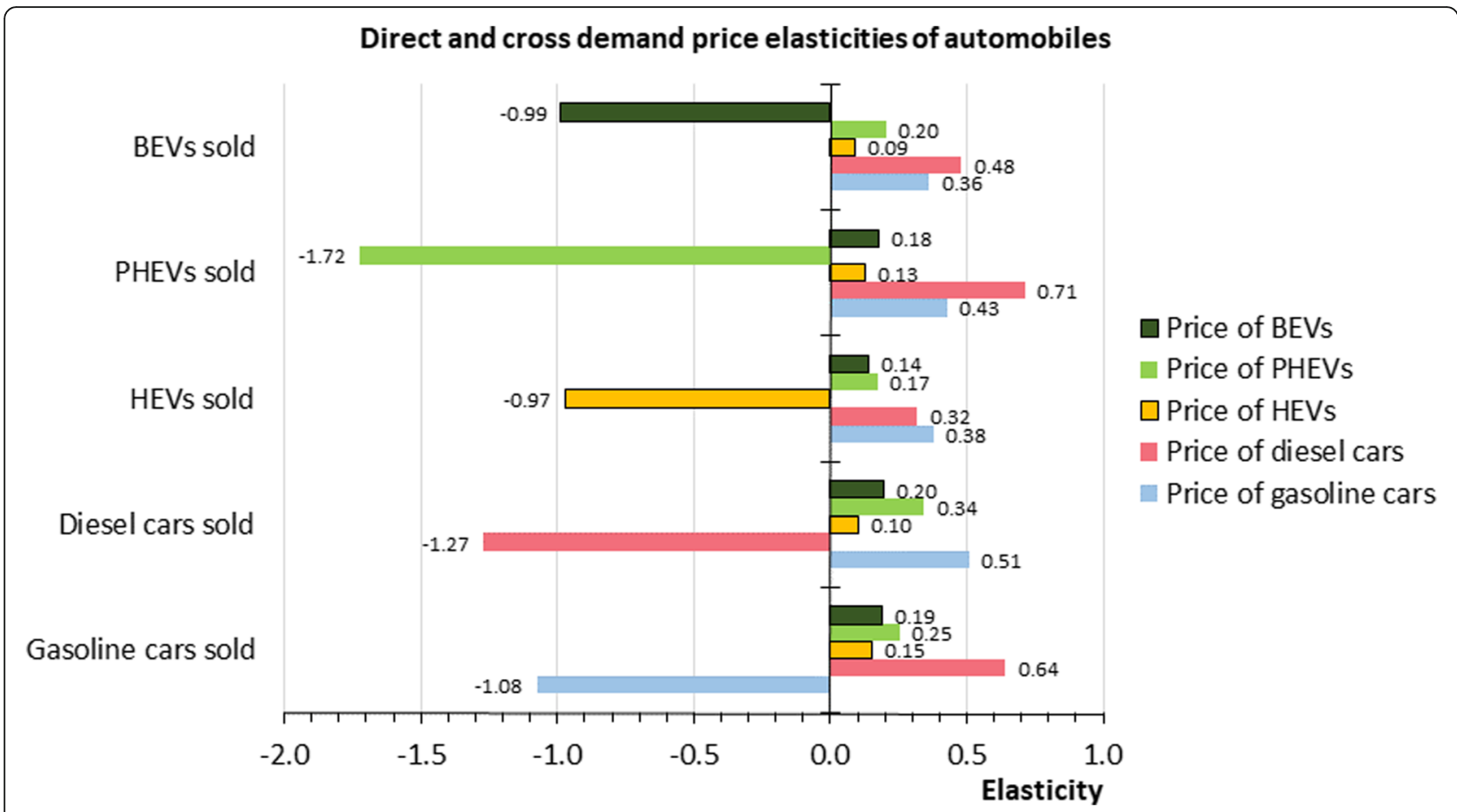

Fig. 6 Price elasticities of demand for automobiles, by vehicle energy technology. Norway 2016

For diesel driven cars, the direct price elasticity comes out at -1.27 . Cross price elasticities of demand for gasoline cars, BEVs, PHEVs and HEVs with respect to the price of diesel cars are estimated at 0.64, 0.48, 0.71 and 0.32, respectively (red bars in Fig. 6).

HEVs and BEVs are slightly less price elastic than gasoline cars, exhibiting own-price demand elasticities of -0.97 and -0.99 . PHEVs, on the other hand, appear to be the most price elastic energy technology in the 2016 Norwegian car market, with an own price elasticity of -1.72 .

\subsection{Automobile demand elasticities with respect to energy prices}

The cars buyers' choices of vehicle model variants depend not only on the retail prices, but also on energy costs. As of 2016 in Norway, the mean retail price of gasoline was NOK $13.55=€ 1.45$ per liter $=$ US $\$ 6.13$ per gallon. The diesel price was NOK $11.66=€ 1.25$ per liter $=$ US $\$ 5.28$ per gallon, and the mean electricity price paid by private households was NOK $0.9675=€ 0.103$ per kWh - all amounts including excise tax and VAT.

In the model, ICE energy costs are entered in the form of discounted future gasoline or diesel expenditures, calculated by multiplying (i) the current real price of fuel by (ii) the vehicle's type approval rate of per $\mathrm{km}$ fuel consumption, by (iii) an assumed $13,000 \mathrm{~km}$ annual mileage, and by (iv) a 17-year automobile life expectancy, consistent with empirical estimates derived by Fridstrøm et al. [26]. A $4 \%$ annual discount rate is applied.

For BEVs, a standard energy consumption rate of 0.2 $\mathrm{kWh} / \mathrm{km}$ is used. For PHEVs, we assume $0.1 \mathrm{kWh} / \mathrm{km}$ of electric energy consumption in addition to the type approval gasoline or diesel consumption. The current real price of grid electricity sold to private households (annual average) is used for cost calculation.

The calculated energy cost expenditure is thus proportional to the current unit price of energy. We can compute elasticities with respect to the fuel and electricity prices simply by varying the capitalized energy cost variable. The elasticities derived are exhibited in Fig. 7.

The elasticity of demand for gasoline cars with respect to the gasoline price is calculated at -0.71 . The 'cross' elasticity of demand for diesel cars with respect to the gasoline price comes out at 0.52. HEVs, PHEVs and BEVs exhibit corresponding elasticities of -0.20, 0.08 and 0.38 , respectively (light blue bars in Fig. 7). Since almost all HEVs run on gasoline, their market shrinks with a higher gasoline price. The PHEVs, on the other hand, are somewhat in the middle: Their competitiveness is more or less unaffected by a gasoline price increase. Although their cost of operation grows, it grows less than for HEVs or for gasoline ICE vehicles. 


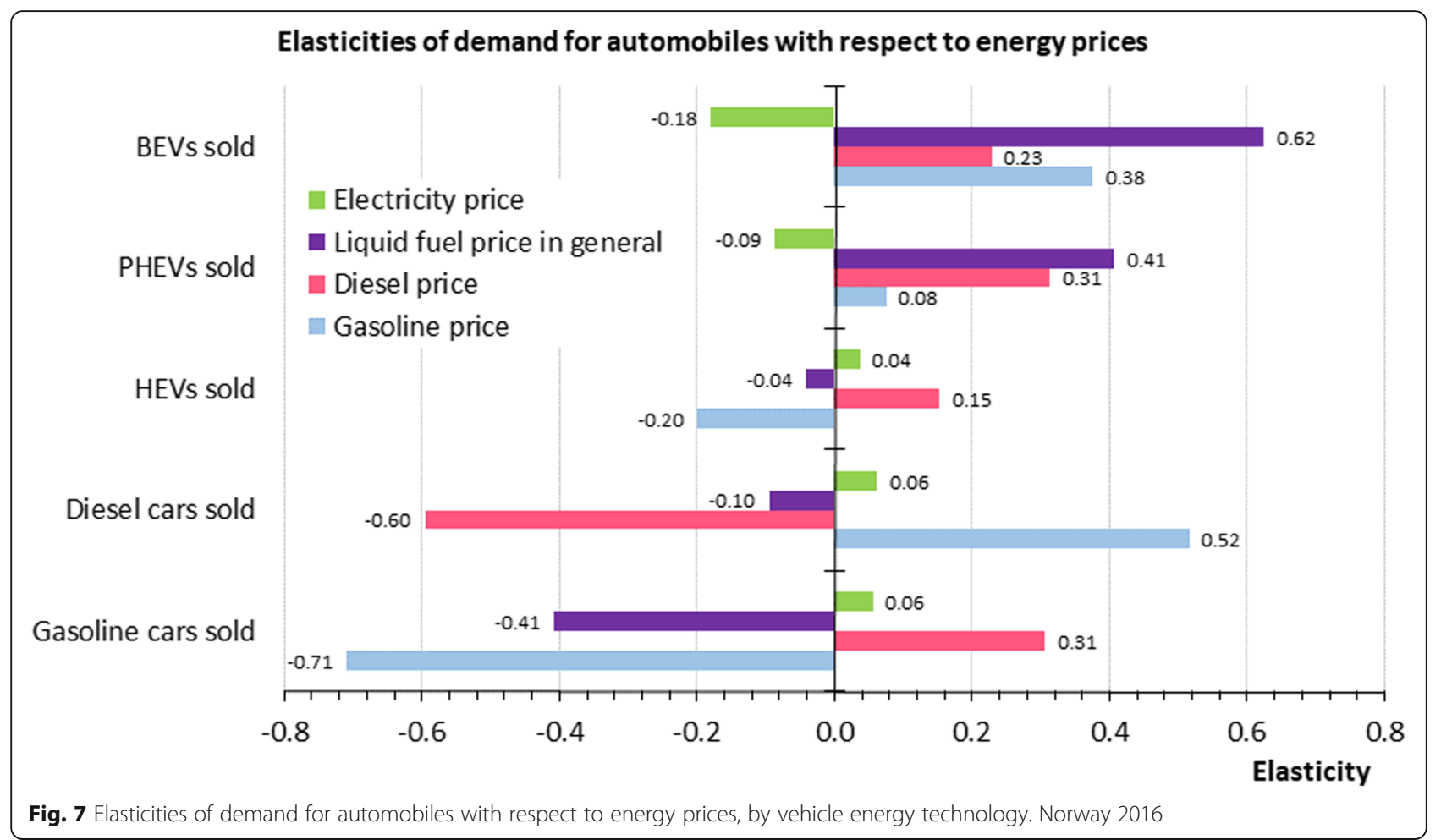

A $1 \%$ diesel price increase will reduce demand for diesel cars by an estimated $0.6 \%$, assuming gasoline and electricity prices to be unaltered (an elasticity of -0.60). The demand for gasoline cars, HEVs, PHEVs and BEVs increases, however, by $0.31,0.15,0.31$ and $0.23 \%$, respectively (red bars in Fig. 7).

Assuming that the prices of all liquid fuel meant for ICEs increase by $1 \%$, the market response is somewhat more 'evened out' between gasoline and diesel vehicles. Gasoline car demand drops by $0.41 \%$ and diesel car demand by $0.10 \%$. Since diesel cars are more energy efficient, they are less hardly hit than gasoline cars by a uniform fuel price surge. HEV demand is almost unaffected, while PHEV demand goes up by $0.41 \%$ and BEV demand by no less than $0.62 \%$, as estimated for 2016 in Norway (purple bars in Fig. 7).

Electricity prices have a lesser impact on vehicle demand. The 'direct' BEV elasticity of demand is estimated at -0.18 . The 'cross' demand elasticities are even smaller (in absolute value) (green bars in Fig. 7). This result must be interpreted in light of the fact that BEVs are three to four times more energy efficient than ICE vehicles, and that electricity in Norway is much cheaper than liquid fuel, as reckoned per unit of energy (kWh).

\section{$5.3 \mathrm{CO}_{2}$ emissions effects}

Changes in the mix of new vehicles registered will, in the long run, affect the composition of the automobile fleet. This in turn will have implications in terms of greenhouse gas (GHG) emissions and climate forcing. Indeed, this is the very rationale for the strong fiscal incentives applied to automobile purchases in Norway, as well as for the more modest incentives applied in a large number of European countries.

In Fig. 8, we show, again in the form of elasticities, calculated changes in the average type approval rate of $\mathrm{CO}_{2}$ emission from new passenger cars as a result of changes in the retail price of new vehicles.

As of 2016 in Norway, a $1 \%$ increase in the list price of gasoline cars would reduce the average type approval rate of $\mathrm{CO}_{2}$ emissions from new passenger cars by an estimated $0.18 \%$. For diesel cars, the corresponding effect is $0.20 \%$. These effects are due to shifts in market demand, as shown in Fig. 6.

A higher price of BEVs will have an almost exactly opposite effect: $+0.19 \%$. Raising the price of PHEVs by $1 \%$ also increases $\mathrm{CO}_{2}$ emissions, by an estimated $0.15 \%$.

The effects of rising energy prices are shown in Fig. 9.

A $1 \%$ gasoline price increase affects the average type approval rate of $\mathrm{CO}_{2}$ emission from new passenger cars 


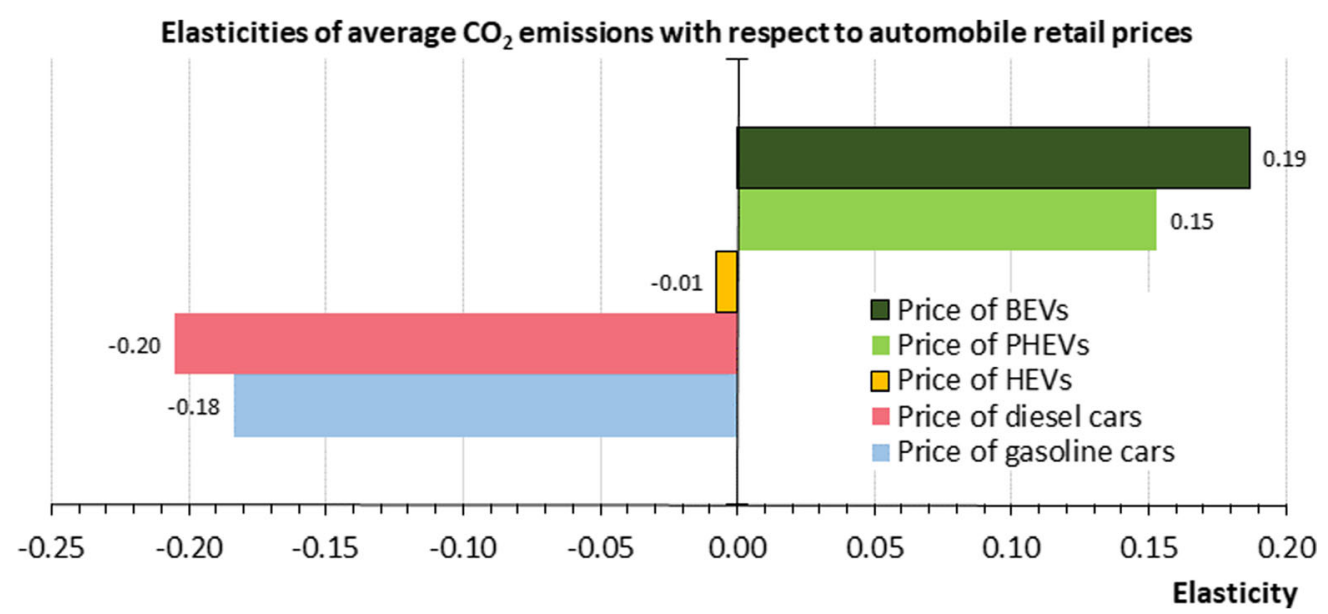

Fig. 8 The effects of vehicle retail prices on average type approval rate of $\mathrm{CO}_{2}$ emissions from new automobiles, by vehicle energy technology. Norway 2016

by an estimated $-0.07 \%$, as of 2016 in Norway. For diesel cars, the corresponding effect is $-0.12 \%$. If both types of fuel become $1 \%$ more expensive, the $\mathrm{CO}_{2}$ emissions impact is $-0.19 \%$. This is so because more people choose zero or low emission vehicles.

Higher prices of electricity will have relatively little effect on vehicle choice, as witnessed by a $\mathrm{CO}_{2}$ emissions elasticity of +0.04 .

\subsection{Willingness to pay for energy savings}

As shown in Table 1, the list price coefficient is estimated at -0.203 , with a standard error of 0.0012 . The $95 \%$ confidence interval stretches from -0.2054 to -0.2007 .
The energy expenditure coefficient estimate comes out at -0.331 , with a standard error of 0.0031 . The $95 \%$ confidence interval goes from -0.3371 to -0.3249 .

By using the calculated net present value of lifetime energy costs rather than simply the per $\mathrm{km}$ fuel cost, we estimate a coefficient that is directly comparable to the list price of the vehicle. The ratio between the two reveals the car buyers' willingness to pay for energy efficiency. We derive an implicit willingness to pay for a future euro saved on energy of 0.331 / $0.203=1.63$ euros.

Hence, at first sight, Norwegian car buyers seem bent on saving energy, even if they lose from it. Could car buyers be so concerned about global warming in general, and about their own environmental footprint in

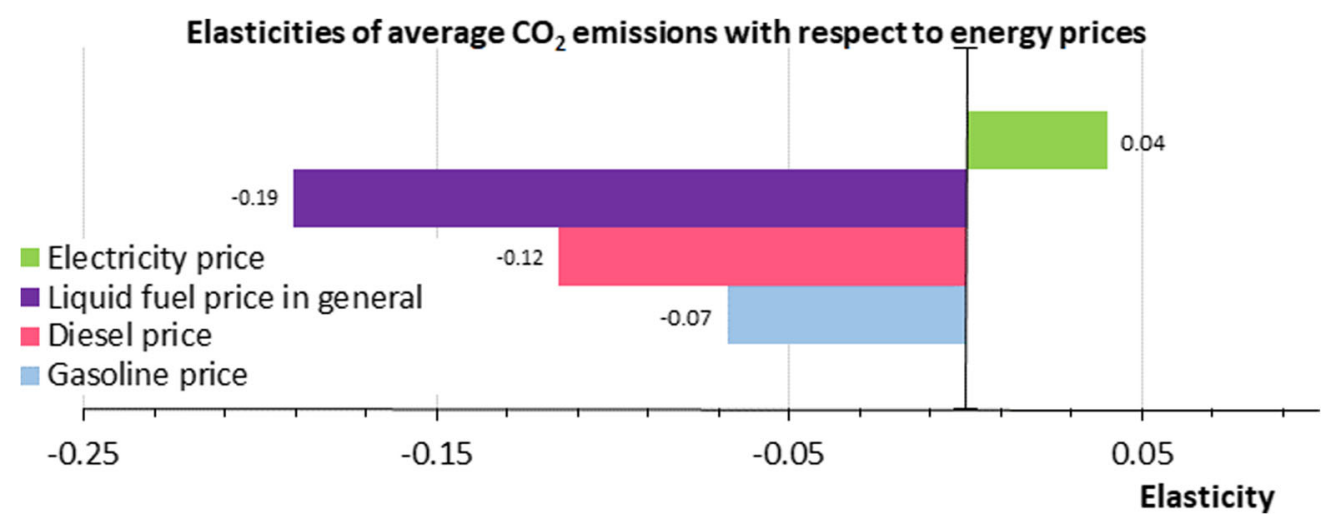

Fig. 9 The effects of energy prices on average type approval rate of $\mathrm{CO}_{2}$ emissions from new automobiles, by energy carrier. Norway 2016 
particular, that they have a strong preference for lean and low emission vehicles per se?

While this altruistic explanation cannot readily be dismissed, there are at least two more possible interpretations, both of them consistent with economic rationality and individual utility maximization.

One possible explanation is that Norwegian car buyers are aware of the large discrepancy between real-world and laboratory (type approval) rates of fuel consumption. According to Tietge et al. [55], the gap between on-theroad and laboratory gasoline or diesel consumption rates has increased from around $10 \%$ in 2002 to $38-40 \%$ for the 2015 to 2017 cohorts of passenger car models sold in the EU.

When energy consumption is measured in terms of laboratory (type approval) rather than real-world rates of fuel use, energy costs are grossly underestimated, and the coefficient estimate is correspondingly overestimated (in absolute value). A correct measure of real world fuel use would lead to a lower fuel cost coefficient. Assume, for the sake of the argument, that a $20 \%$ discrepancy between real-world and laboratory fuel consumption rates applies throughout our sample. A reparametrization to take account of this would lead to an energy cost coefficient of -0.331 / $1.2=-0.276$, yielding a willingness to pay for a euro's worth of future real-world energy savings of $€ 0.276 /$ $0.203=1.36$ euros .

Secondly, it is entirely possible that Norwegian car buyers discount future cash flows at a subjective rate lower than $4 \%$ per annum. Since 2008, Norwegian households, whether they are mortgage borrowers or bank deposit holders, have generally been facing near or below zero after-tax rates of interest. A quite low or zero subjective rate of discount would not be at odds with the market rates of interest.

If consumers are risk averse, and concerned about the prospect of increasing fuel prices, they may hedge against this risk by applying a subjective discount rate lower than the risk neutral rate [34]. In so doing, the car buyer implicitly puts more emphasis on uncertain future energy costs than what follows from standard discounting. Gas guzzlers would be particularly unattractive to these customers, and they might value the high expected future fuel bill almost as if these costs were incurred today.

Had we instead used a zero discount rate, the energy coefficient would have come out at -0.238 , before correcting for laboratory measurement error, implying a $€ 0.238 / 0.203=€ 1.17$ willingness to pay for energy savings in terms of type approval costs. A - say - 20\% uniform laboratory measurement error would be compatible with a $€ 1.17 / 1.2=€ 0.98$ value in real-world terms.
In summary, there is little evidence that Norwegian consumers be 'myopic', in the sense of undervaluing future cash flows. While at odds with Hausman [36], Gately [27] and Houston [40], our estimates concur with the more recent and relevant results of Busse et al. [6].

\section{Discussion}

\subsection{Market shares matter}

We have derived and presented own and cross price elasticities of demand for cars with differing powertrains in Norway as of 2016. Can these be generalized - to other countries or years?

Verbatim: no. Elasticities depend crucially on market shares. In the multinomial logit model, own price elasticities are proportional to the initial price level and to one minus the choice probability (market share) of the alternative in question. Cross price elasticities are proportional to the initial price and to the market share of the alternative whose price is changed ([1]: 111).

In our nested logit model, these formulae will apply literally only within each nest (i.e., make). When we aggregate across all nests and filter results by powertrain, the formulae will apply only approximately.

To fix ideas, consider the cross price elasticity of diesel car demand with respect to the price of BEVs, estimated at 0.20 (Fig. 6), given a BEV market share of $16 \%$, as in Norway in 2016.

To generalize this elasticity estimate to a year and country with a BEV market share of, say, $4 \%$, a rough conjecture would be $0.20 \times 4 / 16=0.05$, assuming the price of BEVs to be the same as in 2016 in Norway.

\subsection{Rebound effects}

A second qualification pertains to the possible rebound effect $[52,53]$ of generally cheaper cars. Ours being a market share model, it does not predict or encompass changes in overall car ownership or aggregate sales. D'Haultfoeuille et al. [8] find, however, that the French feebate (bonus-malus) system for automobiles is counterproductive in terms of $\mathrm{CO}_{2}$ abatement, because the bonus has made car ownership affordable to a larger number of families and thus led to higher aggregate car ownership and use. In Norway, although not a single euro worth of cash subsidies is being paid to people buying electric cars, the tax exemptions for zero exhaust emission vehicles (ZEVs) have enlarged the assortment of relatively inexpensive cars with low operating costs (see Figs. 10 and 11 in Appendix). It is conceivable that this might lead to increased household car 
ownership and use. In our model, it might mean that the own price elasticities of demand for cars are somewhat underestimated (in absolute value).

\subsection{Heterogeneous buyers}

A most important qualification is due to the absence of information about vehicle buyers or owners. Not including buyer information in the model is tantamount to assuming that all buyers are equal. They obviously are not. Since the model contains no information on the human decision makers, it cannot predict trends rooted in changes occurring to these individuals - such as their income, education, family structure, residence pattern, employment, or travel demand.

On the positive side, it must be noted that the model needs no information on vehicles owners or users, or, for that matter, on any social, macroeconomic or other contextual factors, in order to produce a prediction factual or counterfactual. The model is generic, meaning that, in principle, it can predict the market share of a vehicle model that is not yet on the market, as long as the car's relevant attributes are known and fed into the model.

In $2016,48 \%$ of new automobiles in Norway were registered to companies or institutions rather than to persons. The car-owning firms include car rental and leasing companies as well as businesses and government agencies of various kinds. Unfortunately, we do possess any information on the type of company involved. Many of the cars registered to leasing companies are in fact being used by private households.

Among Norwegian car-owning households, some $75 \%$ are able to park their car on their own premises [38]. The remaining $25 \%$ may find it difficult to mount an outlet for vehicle recharging and are hence less likely to buy an electric car. Essentially, this means that our model cannot be expected to generate accurate predictions beyond the point where the share of plug-in electric vehicles (BEVs + PHEVs) approaches $75 \%$.

\subsection{Omitted variables}

With all but two coefficient estimates being different from zero at the $0.1 \%$ level of significance, our nested logit model produces fairly precise estimates of key behavioral parameters as judged by the standard yardsticks of statistical inference.

This does not, of course, mean that our model is immune to specification error. In hedonic regression models, when the demand functions of several heterogeneous products are estimated simultaneously, the risk of confounding price and quality measures is well known. If the product quality is positively related to its manufacturing cost and hence to its price, which then embodies certain quality factors not otherwise accounted for, the numerical value of the price coefficient might be underestimated.

To reduce this risk, we have included in our model a fairly wide set of quality attributes or proxies: make, size, powertrain, fuel efficiency, traction, transmission, body style, and number of doors.

Moreover, we include a measure (named resourcecostshare) capturing the share of the retail price that is not made up by tax. We interpret this term primarily as a summary quality measure reflected in the cost of manufacturing. Elasticities are derived under the implicit assumption that the resourcecostshare variable is kept constant, in other words that prices before and after tax change proportionately.

Yet, compared to the vast array of attributes distinguishing one automobile model variant from another, our discrete choice model captures but a few. Hence we cannot in general rule out omitted variable bias as an important source of error, affecting any one of the model parameters.

In general, the coefficients derived for the various quality attributes included must be interpreted with caution. Some of them may pick up effects due to certain variables not included in the model. A preference for high annual mileage may, e.g., have been captured by the size variable and/or the diesel dummy and trend variables.

Since there are not only two, but five competing powertrains to consider, and since our data set is an exhaustive, maximally disaggregate, 1.8-million strong collection of automobile transactions, our context is considerably more complex than the one described by Verboven [56] (confer Section 2 above). When choosing between powertrains, makes and models, Norwegian buyers are concerned, not only about their future fuel cost, but also about toll, ferry fares, annual ownership tax, parking, access to the bus lane, and possible restrictions on urban driving. None of these contextual factors are explicitly entered into our model. Instead, their combined effects are picked up, in a crude way, by the dummy variables for BEVs, HEVs, PHEVs and diesel ICE vehicles.

The BEV dummy, in particular, is conditioned by the more favorable rate of ownership tax, of NOK $445=€$ 47.60 per annum as of 2016, versus NOK $3135=€ 335$ for a gasoline car. Since the annual tax rates did not change (in real value) between 2002 and 2016, it was impossible to identify this variable as a factor separate from the BEV dummy. 


\subsection{Endogeneity and tax incidence}

Another caveat is endogeneity bias. Automobile retail prices may not be entirely exogenous, as assumed in our model.

Automobile customers routinely pay for add-ons and accessories over and above the standard equipment, although automakers differ in terms of how much equipment they label as 'standard' as opposed to 'extras'. Many auto customers may be able to negotiate rebates or, alternatively, a favorable price for their old car.

The prices entering our data set are, however, not the actual transaction prices, but the manufacturer's suggested retail prices, or list prices, for short. These prices apply to the 'standard' version of each car model and are set uniformly for all dealers in the country. They are not subject to negotiation between dealer and customer.

However, as explained in the literature review (Section 2), we cannot rule out that list prices be affected by the degree of competition between models or by the tax rates applicable to the various car models in a given country. We know from economic theory that a tax wedge serves to lower the price obtained by the seller, while raising the price paid by the buyer. One might suspect that the high and varying purchase taxes in effect in Norway would lead to low markups for ICE vehicles but higher markups for BEVs.

However, Johansen [42] observes a $100 \%$ passthrough rate of automobile taxes in Norway, i.e. the entire tax (increase) is normally passed on to buyers. Yan and Eskeland [59], also studying the Norwegian market, estimate an $88 \%$ pass-through rate. Muehlegger and Rapson [47] find an almost $100 \%$ passthrough rate for the negative tax (subsidy) on electric cars in effect in California.

Even so, it is conceivable that our model could be improved upon through the use of instrumental variables predicting the retail prices, as suggested in the seminal paper by BLP (see Section 2).

We believe, nevertheless, to have reduced the scope for endogeneity bias (i) through the use of list prices rather than actual transaction prices, (ii) through the inclusion of quality attributes and dummy variables for the respective energy technologies, body styles and makes, and (iii) through the inclusion of a diesel trend variable as well as dummy variables capturing the falling popularity of diesel vehicles since 2011. To capture the downward trend in the perceived utility of diesel cars after 2011, we have included a set of five dummies, one for each year 2012-2016. Prior to 2012, on the other hand, the perceived continual improvement of diesel vehicle technology is captured through a logarithmic trend term with a positive coefficient.

In our case, to implement the BLP approach or similar instrumental variable approaches, we would have had to collapse the data set into a less disaggregate form, allowing comparisons to be made between vehicle segments. This procedure would inevitably give rise to certain errors of aggregation. Finding and measuring a relevant set of instruments to predict the retail prices might be difficult.

It appears that even the instrument free, alternative techniques to correct for endogeneity would necessitate a certain amount of aggregation. The same would be true of any data set or model that include individual buyer or owner information in addition to vehicle attributes.

In this first attempt to explore a large and uniquely detailed data set of automobile transactions, we have opted for a simpler, but uncompromisingly disaggregate approach.

\subsection{Suggestions for further research}

To improve and extend the research presented in this paper, a number of options exist.

Most obviously, a reanalysis based on a data set updated until 2019, in which one explores an instrumental variable approach to correct for price endogeneity and tax incidence, would be of interest.

An updated data set filtered by geographic region and type of buyer (corporate or personal) would allow for a host of contextual variables to come into play and help explain the choices made. Municipal data could, e.g., come a long way to quantify the local circumstances affecting the competitiveness of electric cars, such as toll and ferry fare exemption, parking regulations, land use patterns, or bus lanes open to BEVs.

To assess the rebound effect of changing prices, taxes or subsidies, an econometric model of aggregate automobile demand would be needed. As a measure of the 'generalized price' of automobiles over time, the overall log-sum of alternatives emanating from our (updated) nested logit model could possibly be used.

A most promising line of research is the joint modeling of vehicle choice and use underway in the project 'Driving towards the low emission society'. By merging a host of administrative registers, the project team has complied a data base covering the entire adult Norwegian population in 2017. The data base includes income, employment, zones of residence and work, car ownership, license holding, and vehicle mileage data at the individual and household level back to 2009. The data set would allow for uniquely 
accurate and comprehensive analyses of the household decision processes bearing on vehicle energy consumption and technology, road travel demand, greenhouse gas emissions, and local pollutants. Of particular interest is the impact of economic and regulatory policy intervention. A first set of econometric analyses have been delivered by Johansen [42] and Fevang et al. [18].

\section{Conclusions}

We have demonstrated one way to derive direct and cross price elasticities of demand for cars with conventional or alternative energy technology. While the literature is replete with studies on direct demand effects, cross price elasticity estimates do not abound. This is particularly true when it comes to substitution effects involving battery or hybrid electric vehicles. We believe our study to be among the first empirical appraisals of cross price effects between liquid fuel and electricity in road transportation.

Even cross price elasticities between gasoline and diesel vehicles or fuel are hard to come by. Here, too, our study might add to the subject matter insight.

Due to the competition in the automobile market, each energy technology is relatively price elastic. We estimate the own-price elasticity of gasoline driven cars as a whole at -1.08 . That is, if all gasoline cars in the market had their prices increased by $10 \%$, while the prices of all other cars remained unchanged, the number of gasoline cars sold would drop by $10.8 \%$.

Diesel cars and PHEVs are even more price elastic: -1.27 and -1.72 , respectively. In Norway as of 2016, BEVs have an own-price elasticity of almost exactly 1 . The elasticities of demand for gasoline and diesel driven cars with respect to the price of their own fuel are estimated at -0.71 and -0.60 , respectively, assuming in each case that the other fuel prices are kept constant. If, however, both fuel prices increase by 1 $\%$, the demand for gasoline and diesel driven cars changes by -0.41 and $-0.10 \%$.

The cross price elasticities of demand for gasoline cars with respect to the price of diesel cars, and vice versa, are estimated at 0.64 and 0.51 , as of 2016 in Norway. The corresponding 'cross-demand' elasticities with respect to the respective fuel prices are estimated at 0.31 and 0.52 . That is, a $10 \%$ increase in the pump price of gasoline would lift the sale of diesel cars by an estimated $5.2 \%$.

The cross price elasticities of demand for battery electric cars (BEVs) with respect to the prices of gasoline and diesel driven cars are estimated at 0.36 and 0.48 , respectively. The elasticity of BEV demand with respect to the price of all liquid fuel (gasoline and diesel) is estimated at 0.62 .

The apparent, fairly high degree of substitution between vehicle energy technologies means that fiscal policy measures affecting the prices of vehicles and fuel have a considerable potential for changing the long-term composition of the vehicle fleet and its energy consumption, climate footprint and general environmental impact.

Under the tax regime and energy technology market shares prevailing in Norway as of 2016, a $1 \%$ uniform increase in the price of gasoline and diesel would reduce the mean type approval rate of $\mathrm{CO}_{2}$ emissions from new passenger cars by an estimated $0.19 \%$. Thus, as implied by Johansson and Schipper [43], higher fuel prices may well have a stronger long term $\mathrm{CO}_{2}$ mitigation impact through the mean fuel intensity than through the direct travel demand response.

For fruitful inference, the cross demand effects between gasoline, diesel and electricity must be studied at the appropriate point of decision. A societal choice of energy technology is made each time a brand new vehicle is registered. This suggests that fiscal incentives to mitigate $\mathrm{CO}_{2}$ be directed at the decisions made at the car dealer's rather than at the gas station.

Our approach relies on disaggregate discrete choice modeling as applied to a comprehensive and almost complete data set of new automobile transactions. The vast degree of variation in such a disaggregate data set allows for exceptionally precise statistical inference. However, the major drawback of a model based exclusively on vehicle data, like ours, is that it cannot estimate or predict how the auto market responds to changes or constraints affecting the vehicle buyers or owners, be they companies or private households. Thus, among the most important variables omitted in our model are household size, income, and zones of residence and employment. Also, while the buyer's anticipated annual mileage may be determined simultaneously with the choice of vehicle, or help explain it, gathering such information has been outside the scope of our simplified vehicle choice modeling exercise.

Also, since we have not have been able to take proper account of the possible endogeneity of vehicle retail prices, our study should be regarded only as a first attempt to econometrically model automobile choice at the most disaggregate level, exploiting a uniquely detailed and exhaustive vehicle transaction data set for the purpose of own and cross price elasticity estimation. Results could be biased and should be interpreted with caution. 


\section{Appendix}

8.1 Scatterplots

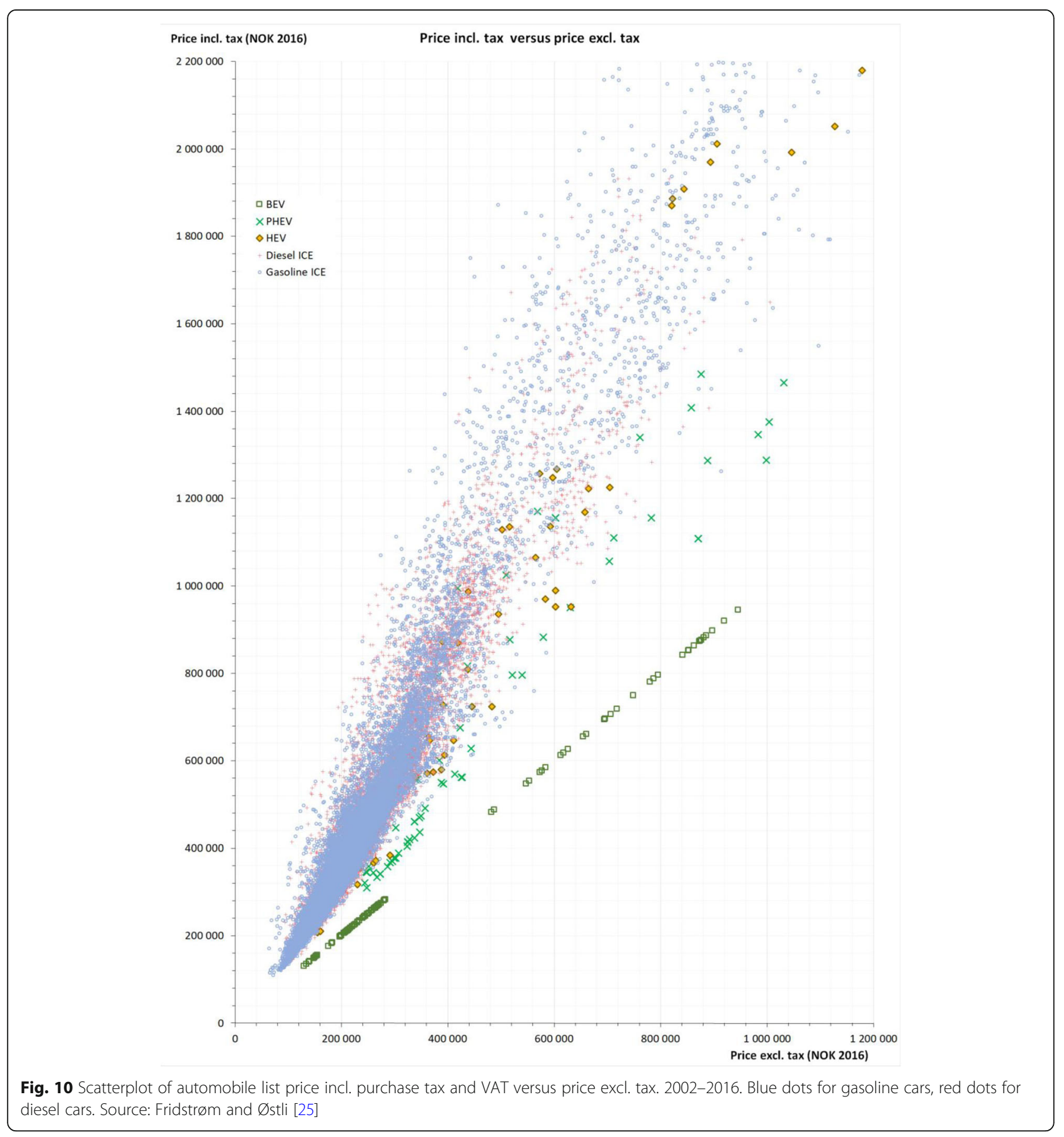




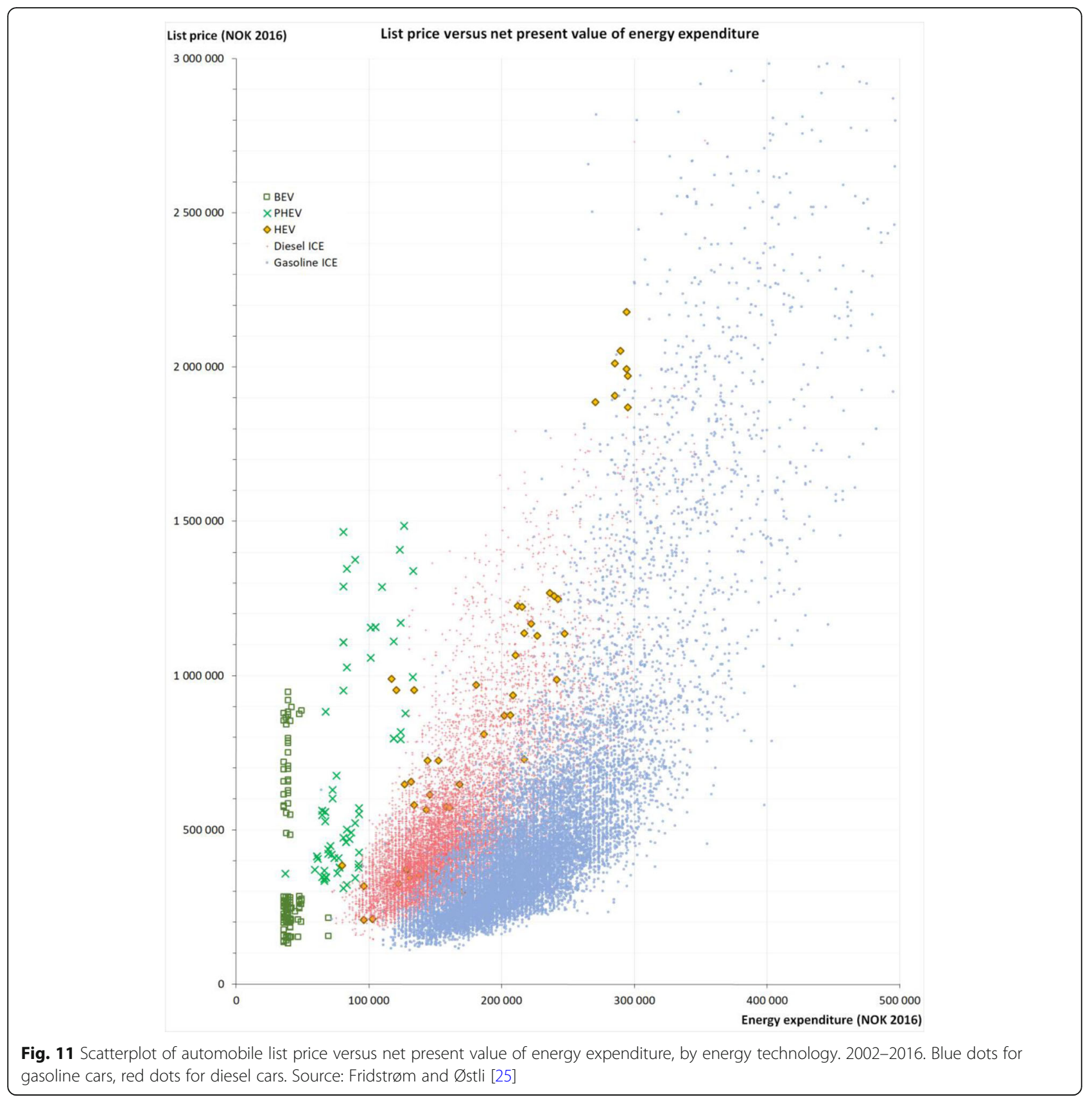




\section{Acknowledgements}

Thanks are due to Bjørn Gjerde Johansen for his professional advice and his help in merging files on disaggregate automobile sales and list prices, to the Norwegian Road Federation (OFV) for providing both sets of data, and to two anonymous referees for their constructive comments, which helped improve the paper.

\section{Sources}

The specifics of the econometric model used, as well as some application results, have previously been documented through technical reports available at the www.toino website, written mostly in Norwegian, but with brief summary in English.

\section{Authors' contributions}

The design of the study and the editing of the manuscript has been the responsibility of the first author. The data preparation, model estimation and calculation of response surfaces were done by the second author. The author(s) read and approved the final manuscript.

\section{Funding}

This research was funded by the Research Council of Norway (grant 280989 'Integrated Transport and Energy Modelling' and grant 267942 'Driving Towards the Low-Emission Society'). The funding body has had no involvement with the design of the study, nor with the collection, analysis or interpretation of data, or with the writing of the manuscript.

\section{Availability of data and materials}

The data that support the findings of this study are available from the Norwegian Road Federation (Opplysningsrådet for veitrafikken - www.ofv. no), but restrictions apply to the availability of these data, which were used under license for the current study, and so are not publicly available. Data are however available from the authors upon reasonable request and with permission from of the Norwegian Road Federation.

\section{Ethics approval and consent to participate}

Not applicable

\section{Consent for publication}

Not applicable

\section{Competing interests}

There are none.

Received: 13 February 2020 Accepted: 28 October 2020

Published online: 04 January 2021

\section{References}

1. Ben-Akiva, M., \& Lerman, S. R. (1985). Discrete Choice Analysis: Theory and Application to Travel Demand. Cambridge: MIT Press.

2. Berkovec, J. (1985). Forecasting automobile demand using disaggregate choice models. Transportation Research Part B: Methodological, 19, 315-329.

3. Berkovec, J., \& Rust, J. (1985). A nested logit model of automobile holdings for one vehicle households. Transportation Research Part B: Methodological, $19,275-285$.

4. Berry, S., Levinsohn, J., \& Pakes, A. (1995). Automobile prices in market equilibrium. Econometrica, 63(4), 841-890.

5. Brons, M., Nijkamp, P., Pels, E., \& Rietveld, P. (2008). A meta-analysis of the price elasticity of gasoline demand. A SUR approach. Energy Economics, 30 2105-2122

6. Busse, M. R., Knittel, C. R., \& Zettelmeyer, F. (2013). Are consumers myopic? Evidence from new and used Car purchases. The American Economic Review, 103, 220-256.

7. Cernicchiaro, G., \& de Lapparent, M. (2015). A dynamic discrete/continuous choice model for forward-looking agents owning one or more vehicles. Computational Economics, 46, 15-34.

8. D'Haulffoeuille, X., Givord, P., \& Boutin, X. (2013). The environmental effect of green taxation: The case of the French Bonus/Malus. The Econometrics Journal, 124, F444-F480.

9. Dahl, C. A. (2012). Measuring global gasoline and diesel price and income elasticities. Energy Policy, 41, 2-13.
10. de Jong, G. C. (1991). An indirect utility model of car ownership and car use. European Economic Review, 34, 971-985.

11. de Jong, G. C. (1996). A disaggregate model system of vehicle holding duration, type choice and use. Transportation Research Part B: Methodological, 30, 263-276.

12. de Jong, G. C. (1997). A micro-economic model of the joint decision on car ownership and car use. In P. Stopher, \& M. Lee-Gosselin (Eds.), Understanding travel behaviour in an era of change. Oxford: Pergamon.

13. Dineen, D., Ryan, L., Gallachóir, Ó., \& B. (2018). Vehicle tax policies and new passenger $\mathrm{car}^{\mathrm{CO}_{2}}$ performance in EU member states. Climate Policy, 18, $396-412$.

14. EFTA Court (2015). Failure by an EFTA state to fulfil its obligations - Directive 2008/50/EC on ambient air quality and cleaner air for Europe - Limit values for certain pollutants in ambient air - Air quality plan. Judgment of the Court in Case E-7/15, 2 October 2015

15. Enova (2018). Annual report 2017. Trondheim: Enova SF

16. Espey, M. (1998). Gasoline demand revisited: An international meta-analysis of elasticities. Energy Economics, 20, 273-295.

17. EU (2019). Regulation (EU) 2019/631 of the European Parliament and of the Council of 17 April 2019 setting CO2 emission performance standards for new passenger cars and for new light commercial vehicles, and repealing regulations (EC) No 443/2009 and (EU) No 510/2011. Official Journal of the European Union, L 111, 13-53 (25 April 2019).

18. Fevang, E., Figenbaum, E., Fridstrøm, L., Halse, A. H., Hauge, K. E., Johansen, B. G., \& Raaum, O. (2020). Who goes electric? Characteristics of electric car ownership in Norway 2011- 2017. TØI Report 1780. Oslo: Institute of Transport Economics. Available here https://www.toi.no/getfile.php?mmfileid=53659.

19. Figenbaum, E. (2017). Perspectives on Norway's supercharged electric vehicle policy. Environmental Innovation and Societal Transitions, 25, 14-34.

20. Figenbaum, E., Assum, T., \& Kolbenstvedt, M. (2016). Electromobility in Norway: Experiences and opportunities. Research in Transportation Economics, 50, 29-38.

21. Figenbaum, E., \& Kolbenstvedt, M. (2016). Learning from Norwegian Battery Electric and Plug-in Hybrid Vehicle Users. Results from a survey of vehicle owners. TØI Report 1492. Oslo: Institute of Transport Economics.

22. Fridstrøm, L. (1999). Econometric models of road use, accidents and road investment decisions. Volume II. TØI Report 457. Oslo: Institute of Transport Economics.

23. Fridstrøm, L. (2019). Dagens og morgendagens bilavgifter. TØI Report 1708. Oslo: Institute of Transport Economics Available here: https://www.toi.no/ getfile.php?mmfileid=51124.

24. Fridstrøm, L. (2020). Taxation or subsidization? Explaining Norway's record fast market uptake of electric cars. Poster 975, TRA2020 Conference, Helsinki.

25. Fridstrøm, L., \& Østli, V. (2018). Etterspørselen etter nye personbiler - analysert ved hjelp av modellen BIG. TØI Report 1665. Oslo: Institute of Transport Economics.

26. Fridstrøm, L., Østli, V., \& Johansen, K. W. (2016). A stock-flow cohort model of the national car fleet. European Transport Research Review, 8, 22.

27. Gately, D. (1980). Individual discount rates and the purchase and utilization of energy-using durables: Comment. Bell Journal of Economics, 11, 373-374.

28. Gillingham K (2012). Selection on anticipated driving and the consumer response to changing gasoline prices. Unpublished paper, Yale University. http://www.idep.eco.usi.ch/media/pages/seminars/past-seminars/2011/9144 7eff6f-1605049799/paper-gillingham-186992.pdf

29. Gillingham K, Iskhakov F, Munk-Nielsen A, Rust J, Schjerning B (2015). A Dynamic Model of Vehicle Ownership, Type Choice, and Usage. Unpublished manuscript, Yale University, downloadable at http://bschjerning.com/ papers/iruc.pdf

30. Gillingham K, Iskhakov F, Munk-Nielsen A, Rust J, Schjerning B (2016). A dynamic model of vehicle ownership, type choice, and usage. Unpublished manuscript. http://bschjerning.com/papers/iruc.pdf.

31. Glerum, A. E., Frejinger, E., Karlström, A., Beser Hugosson, M., \& Bierlaire, M. (2014). A dynamic discrete-continuous choice model of car ownership and usage. In STRC 14th Swiss transport research conference. Switzerland: Monte Verità/Ascona

32. Hagman, R., \& Amundsen, A. H. (2013). Utslipp fra kiøretøy med Euro 6N teknologi. Måleprogrammets fase 2. TØI Report 1291. Oslo: Institute of Transport Economics.

33. Hagman, R., Gjerstad, K. I., \& Amundsen, A. H. (2011). NO $\mathrm{N}_{2}$-utslipp fra kjøretøyparken i norske storbyer. Utfordringer og muligheter frem mot 2025. TØI Report 1168. Oslo: Institute of Transport Economics. 
34. Hatlebekk, M., \& Moxnes, E. (1993). Informasjonstiltak som supplement til $\mathrm{CO}_{2}$-avgift. Sosialøkonomen, 47(3), 2-5.

35. Hauff, K., Pfahl, S., \& Degenkolb, R. (2018). Taxation of electric vehicles in Europe: A methodology for comparison. World Electric Vehicle Journal, 9, 30.

36. Hausman, J. A. (1979). Individual discount rates and the purchase and utilization of energy-using durables. Bell Journal of Economics, 10, 33-54.

37. Havranek, T., Irsova, Z., \& Janda, K. (2012). Demand for gasoline is more price-inelastic than commonly thought. Energy Economics, 34, 201-207.

38. Hjorthol, R., Engebretsen, $\varnothing ., \&$ Uteng, T. P. (2014). Den nasjonale reisevaneundersøkelsen 2013/14 - nøkkelrapport. TØI Report 1383. Oslo: Institute of Transport Economics.

39. Hössinger, R., Lin, C., Sonntag, A., \& Stark, J. (2017). Estimating the price elasticity of fuel demand with stated preferences derived from a situational approach. Transportation Research Part A, 103, 154-171.

40. Houston, D. A. (1983). Implicit discount rates and the purchase of untried, energy-saving durables. Journal of Consumer Research, 10, 236-246.

41. ICCT (2020). European vehicle market statistics. Pocketbook 2019/20. Berlin International Council on Clean Transportation.

42. Johansen, B. G. (2020). Car ownership, driving and battery electric vehicles. Dissertation for the Ph.D. degree, Department of Economics, University of Oslo.

43. Johansson, O., \& Schipper, L. (1997). Measuring the long-run fuel demand of cars: Separate estimations of vehicle stock, mean fuel intensity, and mean annual driving distance. Journal of Transport Economics and Policy, 31, 277-292.

44. Labandeira, X., Labeaga, J. M., \& López-Otero, X. (2017). A meta-analysis on the price elasticity of energy demand. Energy Policy, 102, 549-568.

45. Lave, C. A., \& Train, K. (1979). A disaggregate model of auto-type choice. Transp. Res. Part A: Policy and Practice, 13, 1-9.

46. Manski, C. F., \& Sherman, L. (1980). An empirical analysis of household choice among motor vehicles. Transportation Research Part A: Policy and Practice, 14, 349-366.

47. Muehlegger, E. and Rapson, D. S. (2018). Subsidizing mass adoption of electric vehicles: Quasi-experimental evidence from California. NBER Working Paper 25359, National Bureau of Economic Research, Cambridge, Massachusetts.

48. Munk-Nielsen, A. (2015). Diesel cars and environmental policy. Dept. of Economics, University of Copenhagen http://web.econ.ku.dk/munk-nielsen/ papers/diesel.pdf.

49. Odeck, J., \& Johansen, K. (2016). Elasticities of fuel and traffic demand and the direct rebound effects: An econometric estimation in the case of Norway. Transportation Research Part A, 83, 1-13.

50. Østli, V., Fridstrøm, L., Johansen, K. W., \& Tseng, Y. (2017). A generic discrete choice model of automobile purchase. European Transport Research Review, 9, 16.

51. Royal Ministry of Finance (2017). Notification of tax measures for electric vehicles. Letter to the the EFTA Surveillance Authority, November 6, 2017, Oslo.

52. Schipper, L., \& Grugg, M. (2000). On the rebound? Feedback between energy intensities and energy uses in IEA countries. Energy Policy, 28, 367-388.

53. Small, K., \& van Dender, K. (2005). The effect of improved fuel economy on vehicle miles travelled: Estimating the rebound effect using U.S. state data, 1966-2001. Berkeley: University of California Energy Institute: Policy and Economics https://citeseerx.ist.psu.edu/viewdoc/download?doi=10.1.1.192.1 737\&rep=rep $1 \&$ type $=$ pdf.

54. Strand, A., Aas, H., Christiansen, P., Nenseth, V., \& Fearnley, N. (2010). Bergen vinteren 2010. Evaluering av tiltak mot lokal luftforurensing. TØI Report 1091. Oslo: Institute of Transport Economics.

55. Tietge, U., Díaz, S., Mock, P., Bandivadekar, A., Dornoff, J., \& Ligterink, N. (2019). From laboratory to road. In In A 2018 update of official and "real-word" fuel consumption and $\mathrm{CO}_{2}$ values for passenger cars in Europe. Berlin: ICCT.

56. Verboven, F. (2002). Quality-based price discrimination and tax incidence: Evidence from gasoline and diesel cars. The RAND Journal of Economics, 33(2), 275-297.

57. Wappelhorst, S., Mock, P., \& Yang, Z. (2018). Using vehicle taxation policy to lower transport emissions. An overview for passenger cars in Europe. Berlin: International Council on Clean Transportation.

58. Weber, C., Hagman, R., \& Amundsen, A. H. (2015). Utslipp fra kjøretøy med Euro 6NI teknologi. Resultater fra måleprogrammet i EMIROAD 2014. TØ Report 1405. Oslo: Institute of Transport Economics.
59. Yan, S., \& Eskeland, G. S. (2018). Greening the vehicle fleet: Norway's $\mathrm{CO}_{2}-$ differentiated registration tax. Journal of Environmental Economics and Management, 91, 247-262.

60. Zaefarian, G., Kadile, V., Henneberg, S. C., \& Leischnig, A. (2017). Endogeneity bias in marketing research: Problem, causes and remedies. Industrial Marketing Management, 65, 39-46.

\section{Publisher's Note}

Springer Nature remains neutral with regard to jurisdictional claims in published maps and institutional affiliations.

\section{Submit your manuscript to a SpringerOpen ${ }^{\circ}$ journal and benefit from:}

- Convenient online submission

- Rigorous peer review

- Open access: articles freely available online

- High visibility within the field

- Retaining the copyright to your article

Submit your next manuscript at $\boldsymbol{\nabla}$ springeropen.com 